\title{
A Metallurgical Perspective on the Birth of Ancient Israel
}

\author{
NISSIM AMZALLAG \\ Department of Bible, Archaeology and Ancient Near Eastern Studies, Ben Gurion University of the \\ Negev, Beer Sheba, Israel
}

\begin{abstract}
The re-emergence of the copper industry in the Arabah valley between the twelfth and ninth centuries BCE stimulated wealth and economic development across the whole Southern Levant. Combining this reality with the metallurgical background of ancient Yahwism provides a material basis for the spread, from the early Iron Age, of the worship of YHWH in ancient Israel and neighboring nations, especially Edom. These findings strengthen the Qenite hypothesis of the origin of the Israelite religion. They also suggest that an official cult of YHWH, replacing a traditional esoteric dimension, is the main novelty of the Israelite religion. The claim of YHWH's intervention in history, apparently absent from traditional Yahwism, is the other theological novelty advanced by the Israelites. This article suggests that both innovations are rooted in a desert-shaped form of Yahwism especially adapted to the way of life and the environment of Northwestern Arabia, the land of Biblical Midian.
\end{abstract}

KEYWORDS Qenite hypothesis, copper metallurgy, Qurayyah ware, pre-Israelite Yahwism, biblical mythology, Early Israelite Yahwism

\section{Introduction}

Fifty years ago, Mircea Eliade wrote that "the discovery of metals and the progress of metallurgy radically modified the human mode of being in the universe. Not only did the manipulation of metals contribute considerably to man's conquest of the material world; it also changed his world of meaning. The metals opened for him a new mythological and religious universe" (Eliade 1968, 76). This claim is confirmed today by many anthropological studies revealing the religious dimension of metallurgy and its centrality in traditional societies from Africa and India (Richards 1981; Van der Merwe, Avery, and Avery 1987; Reid and MacLean 1995; Barndon 2005). The same conclusion arises from the ancient Near East religions, especially from the Bronze Age. Ptah, the Egyptian god of smiths, was the chief deity of the Memphis theology, granted with demiurgic and vitalizing powers (Finnestad 1976, 83, 93; 
Kakosy 1980, 48-53). Velkhanos, his Minoan homolog, enjoyed a similar status as the greatest god of Crete (Bloedow 1991, 166; Capdeville 1995, 179-80). In Mesopotamia, the god of smiths Enki/Ea was among the essential deities, identified as the creator of man, the master of wisdom, and even the protector of humankind against all the other deities.

But curiously, the religious importance of metallurgy is apparently absent from the Levant. Kothar, the god of smiths of the Ugarit mythology, is a second-rank deity fulfilling the instructions of $\mathrm{El}$ and the main gods. The identity of his homolog from Southern Levant is unknown. This situation is intriguing, however. We would expect metallurgy to be of great importance in the Southern Levant in light of the copper mining activity attested in the Arabah, from the Chalcolithic period to the Iron Age. This absence is especially unexpected because the Southern Levant is one of the few places from which metallurgy originated. It is even the site of emergence of the technique of copper production in a furnace, the homeland from where it spread across the ancient Near East (Amzallag 2009a). Furthermore, metallurgy was of central importance in the development of the Ghassulian (Chalcolithic) society and its universe of beliefs (Gosić 2013, 281-84; Gosić and Gilead 2015a), and this craft remained of economic importance at the beginning of the Bronze Age. This is why a famous indigenous deity probably patronized metallurgy in the Southern Levant.

Looking for this deity leads us to investigate the traditions of the South Levantine metalworkers. Not a lot is known about them, their way of life, and their beliefs. But we may identify them with the biblical Qenites, this name being derived from the root qyn, which designates metalworking in old Canaanite languages (Amzallag and Yona 2017). Their metallurgical acquaintance is confirmed by the integration of the father of the smiths (Gen 4:22) in the Cain genealogy and the description, in this genealogy, of the typical lifestyle of ancient metalworkers (Sawyer 1986; McNutt 1990, 235-49; Mondriaan 2010, 312-20).

Biblical scholars have devoted special attention to the Qenites because some indications suggest their closeness to YHWH even before the rise of Israel. The following pieces of evidence point to this conclusion:

- Cain, the forefather of the Qenites, is the first-born of humanity (Gen 4:1-2). He is also the first man offering to YHWH (Gen 4:3).

- Moses's discovery of YHWH happens in a Qenite context. The incident occurs in the vicinity of the camp of Jethro, his father-in-law is identified as a Qenite priest of Midian (Ex 3:1 and Judg 1:16).

- In Exodus 18, Jethro is the priest who conducts the ritual to YHWH in the presence of Moses, Aaron and the elders of Israel (Ex 18: 12). This reflects his prestige even in the eyes of the Israelite religious elite.

- The Rechabites, a branch of the Qenites, are mentioned both in the book of Kings ( $2 \mathrm{Kgs}$ 10:15-16) and in Jeremiah 35 (Jer 35: 18-19) for their well-known zeal for YHWH.

- The southern origin of the Qenites and their closeness to Edom, Midian and Amaleq corroborates the Southern origin of YHWH claimed in some ancient biblical hymns (Judg 5:5; Deut 33:2; Hab 3:3).

These indications (and others) led scholars from the nineteenth century to the present day to assume a Qenite origin of the worship of $\mathrm{YHWH}$, and even a Qenite ascendant of early Israelite theology (see Blenkinsopp 2008, 131-33; Mondriaan 2010, 307-405 for review). However, this Qenite influence is not explicit in the Bible, where their role is officially limited to assisting the Israelites and guiding them during their wanderings in the desert (Num 10:31; 
1 Sam 15:6). In Genesis, the Qenites are even intentionally excluded from the grand genealogy of humanity, beginning with the birth of Seth (Gen 4:25-26) and extending with Noah and his sons (Amzallag 2018b). The book of Genesis even includes them in the list of peoples to be dispossessed of their dominion by the sons of Abraham (Gen 15:19). The ambivalent situation of the biblical authors in regard to the Qenites is unhelpful for evaluating the likelihood of the Qenite hypothesis and reconstituting the pre-Israelite Yahwism.

A detail may, however, help us. Metalworkers were specialized artisans in Antiquity. Consequently, if the Qenites originally worshiped YHWH specifically, we may presume that metallurgy was among his essential attributes. In other words, YHWH may have been the mysterious smelting god of the Southern Levant whose identity remained hidden until the rise of Israel. In the first part of this paper, I would like to show elements supporting this premise. The second part will question how the god traditionally sponsoring metalworking became the patron-deity of Israel, and how some desert traditions from northwestern Arabia (the biblical land of Midian) influenced such a process. But I would like to introduce some preliminary remarks beforehand. First, the metallurgical dimension of ancient Yahwism has been entirely ignored throughout the last two centuries of biblical research, even by those scholars promoting the Qenite theory. Therefore, all the biblical references quoted here have received a plethora of explanations outside of the metallurgical context. It remains impossible to discuss these alternative views without transforming this essay into a voluminous book. Here, I would like to cover a brief overview of the metallurgical roots of Israelite Yahwism and its Qenite ascendant to offer a new perspective on the origin of ancient Israel and its cult of YHWH. This perspective should expose a coherent representation with a minimum of ad hoc hypotheses, and will resolve some outstanding questions.

The second remark concerns the exploitation of biblical writings for reconstituting the history of ancient Israel. The use of biblical writings is generally impossible without extracting the historical kernel from its gangue of literary developments. A massive apparatus of form-criticism developments is generally necessary for such a purpose. But their use is more straightforward concerning the metallurgical background of ancient Yahwism and its historical roots, because this metallurgical background was not a central part of the Israelite religion when most of the biblical opuses were composed (from the end of the monarchic period to the end of the Persian period). These centuries are characterized by a conflict with Edom (Hoekveld-Meijer 1996, 77-90, 232-70; Dicou 1994, 182-97; Assis 2016), the nation identified with the production of copper in the Southern Levant. In such an ideological climate, the references to the metallurgical background of the Israelite religion and to a Qenite/Edomite origin of YHWH's cult are certainly not apologetic literary developments defending the Israelite rhetoric and theology of this time. Instead, their counter-productive effect regarding the anti-Edomite ideology suggests that their insertion reflects the need to confer realism to the narrative. This realism is why, even in the absence of extensive form-criticism developments, we may conclude that the elements promoting a metallurgical background of ancient Yahwism in the Bible belong to the historical kernel rather than its literary gangue.

The third remark concerns our understanding of the religious dimension of metallurgy in Antiquity. Today, a reference book highlighting the cultural component of metallurgy in both the Bronze and Iron Age, based on archaeology, iconography, symbolism, and literary sources, is still missing. Exposing developments and conclusions is not always easy in light of such a lacuna. The cultural and religious dimensions of metallurgy are particularly ignored in biblical studies and the archaeology of the ancient Near East. The gods sponsoring metallurgy are 
generally approached as minor deities, artisan gods creating tools and artifacts for the main deities, benefitting a broad devotion.

Furthermore, the rare investigations exploring the religions dimension of metallurgy and its significance are, for the most, inspired by the anthropological studies performed on iron metallurgy in traditional societies from Africa (e.g. Williamson 1990, 81-92; 106-107; Haaland 2004; Berggren 2004; Rotea et al. 2011; Gosić and Gilead 2015b). However, their extrapolation remains a challenge as long as the dominant metal was copper as there is an essential difference in the symbolism of the production of these two metals. In Antiquity, copper was smelt in a furnace while iron remained in a solid-state throughout its production phases. Only a few works, such as the seminal book of Kristianssen and Larrson (The Rise of the Bronze Age Society, Kristiansen and Larsson 2005), noted the cultural importance of copper metallurgy, in stressing its status as the esoteric fundament of the Bronze Age religions and the ancient Near East as the homeland of this doctrine. After these preliminary remarks, we can now start.

\section{Metalworkers as YHWH's Religious Elite}

The few indications concerning the Qenite worship of YHWH are not the only evidence supporting the assumption of metallurgical background of ancient Yahwism. For example, some biblical sources grant the metalworkers the outstanding status of emissaries of YHWH.

- Zechariah oracle: In an oracle from Zechariah, the prophet envisions YHWH sending four metalworkers to emancipate the Israelites from oppression: “ ${ }_{3}$ Then YHWH showed

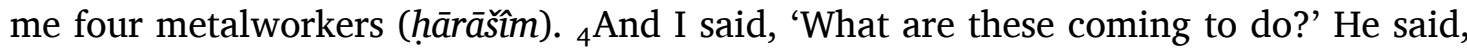
'These are the horns that scattered Judah, so that no one raised his head. And these [four] have come to terrify them, to cast down the horns of the nations who lifted up their horns against the land of Judah to scatter it' " (Zech 2:3-4). These four liberators are not identified as Israelite leaders. They are no more considered divine agents. Rather, their mere designation as metalworkers is enough for identifying them as emissaries of YHWH, granted with the powers to expel those nations persecuting Israel.

- Jacob in Mahanaim: In Genesis 32, we read that Jacob meets people in Mahanaim whom he identifies immediately as emissaries of YHWH: " ${ }_{2} \mathrm{Jacob}$ went on his way, and the emissaries of God (mal'ăkê 'ĕlōhîm) met him. ${ }_{3}$ And when Jacob saw them he said, 'This is God's camp!' (maḥănēh 'ělōhîm) So he called the name of that place Mahanaim. ${ }_{4}$ And Jacob sent emissaries (mal'âkîm) before him to Esau his brother in the land of Seir, the country of Edom." The term mal'āk 'ělōhîm /YHWH frequently refers to a divine emissary. But in the Bible, this expression may also designate people speaking or acting in the name of YHWH, such as prophets (Judg 2:1,4; 5:23; Isa 42:19; 44:26) and priests (Mal 2:7). ${ }^{1}$ This latter meaning is probably relevant in Gen 32:2, because Jacob is not frightened by meeting these emissaries. The reiterated use of the term mal'a $\bar{k}$ for designating human messengers, two verses later, strengthens their human nature. Here, the most striking feature is Jacob immediately identifying these people as emissaries of YHWH, in Gen 32:2. The only detail added concerning them, which may justify this status, is their presence on this site (Gen 32:3). Mahanaim is located in the region of

1 The notion of a human emissary of YHWH is also reflected by the expression 'î̌s 'èlohhîm attached to Moses (Deut 33:1; Jos 14:6), the messenger par excellence of YHWH, and to the prophets (1 Sam 2:27; 9:6-10; 1 Kgs 12:22; 13:1,4-31; 20:28). 
Deir Alla, which was the hearth of intense metallurgical activity at the end of the second millennium BCE (Veldhuijzen and Van der Steen 1999, 195, 198; Negbi 1998, 196; Tebes 2007,82$)^{2}$ Consequently, the people that Jacob identified as emissaries of YHWH and inhabiting this site were probably metalworkers. And if the author of Genesis tells us that Jacob identified them as emissaries of YHWH even before speaking with them, seeing or hearing about their deeds, we may conclude that this status was inherent to their nature of metalworkers.

- Moses's legitimacy as emissary: Many biblical sources present Moses as the archetype of the emissary of YHWH. However, to convince the Israelites of his status, Moses has to perform a wonder: the reversible transformation of a scepter into a serpent. From Ex 4:1-5, we understand that this prowess is enough to ensure that YHWH sent Moses to the Israelites. It is not an exceptional feature, however. The book of Exodus claims that the Egyptian specialists are capable of reproducing it readily (Ex 7:11-12). This wonder therefore requires a particular skill, which is identified with YHWH by the Israelites. The nature of this wonder remains imprecise in this story, but the wordplay between serpent (nāḥ̄aš) and copper (nāḥ̄aš /nẹḥōšet) invites us to look for a metallurgical context of interpretation. Its performance near a source of intense heat (the burning bush) supports this presumption. It even suggests that the wonder is nothing less than the transformation of a copper artifact (the scepter) into liquid copper (the serpent), from which a new scepter is produced (Amzallag 2009b, 396). In other words, the wonder becomes a demonstration of Moses' metallurgical skill, granting him the status of emissary of YHWH in the eyes of the Israelites.

The attribution to Moses of the Nehushtan, the cultic copper serpent in the Jerusalem temple (2 Kgs 18:4), and the reference that he made it himself (Num 21:8) confirm that metalworking was attached to the figure of Moses in the Israelite tradition. Aaron knows how to perform the scepter-serpent reversible transformation (Ex 7:9-10). This indicates that Aaron, the archetype of the Israelite priest, is also identified in Exodus as a metalworker. His fabrication of the Golden Calf (Ex 32:1-5) confirms this premise. In verse 1, the people address Aaron not as a great priest but as an artisan when they order him: "make us ('ăsể lānû) a god." Aaron answers this request like a metalworker does: if the Israelites want a statuette, they have to supply the metal ("Take off the rings of gold that are in the ears of your wives, your sons, and your daughters, and bring them to me," Ex 32:2). The people bring the metal to Aaron (v. 3), who prepares the mold, melts the metal, and casts it (v. 4). The significance of this description is generally minimized at the expense of the parallel between the story of the Golden Calf (Exodus 32) and the reference to calves introduced by king Jeroboam in the Israel kingdom (1 Kings 12) (Dozeman 2009, 686; Hundley 2017, 562). ${ }^{3}$ However, the author of Exodus 32 stresses a critical feature: Aaron, the figure of the first priest in Israelite history, was familiar with metallurgy and its cultural dimension.

The son of Aaron, Eleazar, is also granted metallurgical skills. This is revealed in Numbers, through the verses mentioning the treatment of the copper-made incense burners of Korah and his company. In Num 16:38-39, we read that Eleazar hammered these copper artifacts to transform them into plates of copper set on the copper-coated altar of the tabernacle. Lamina-

2 The Book of Kings (1 Kgs 7:46) mentioning the massive copper artifacts of the Jerusalem temple produced in this region confirms its metallurgical character.

3 See for example the parallel claims in Gen 32:4 and $1 \mathrm{Kgs} \mathrm{12:28.}$ 
tion by cold hammering is a delicate task, revealing, here again, a metallurgical skill attached to an early figure of priesthood in Israel.

Beyond the priestly and prophetic functions of the metalworkers, it seems that their metallurgical activity was endowed with a divine dimension. In Exodus, Bezalel, the metalworker and polyvalent craftsman constructing the tabernacle, is spontaneously considered filled with the "spirit of YHWH" (Ex 35:30-34). The content of Isa 54:16 suggests that this closeness to YHWH is especially conditioned by their craft. The first half of this verse claims that YHWH is not only present in the forge, but also involved in the blasting of fire and even in casting the molten metal: "Behold, it is I who created the smith, who fans the coals into flame and forges a weapon fit for its work" (see Amzallag and Yona 2018). ${ }^{4}$ This divine participation transforms the metalworker into a collaborator of $\mathrm{YHWH}$ and, by extension, into his emissary.

The closeness to YHWH granted the metalworkers the status of semi-gods. The birth of Cain, in which YHWH is apparently actively involved, insinuates this: "Now Adam knew Eve his wife, and she conceived and bore Cain, saying, 'I have created (qānîtî) a man with [the help of] YHWH'" (Gen 4:1). The same semi-god nature of the metalworkers appears in Isa 44:10-11, two verses denouncing the metalworkers for casting statuettes for religious purposes (like Exodus 32 denounces Aaron for casting the Golden Calf and organizing a festival for YHWH through its worship). Unlike in Exodus (where Aaron's high-priest status is unchanged after the fabrication of the Golden Calf), this sermon exploits the production of cultic statuettes for undermining the prestigious status of the metalworkers: " ${ }_{10}$ Who fashions a god or casts a statuette that is profitable for nothing? ${ }_{11}$ Behold, all his companions shall be ashamed (yēbōšû), the metalworkers are only human. They shall all assemble, stand, fear; they shall be confounded together (yēbōšû yāḥad)." Here, the double mention of yēbōšû ("ashamed, confounded") suggests that the metalworkers should be aware of the inefficiency of the cultic statuettes they produce. ${ }^{5}$ Especially interesting here is the claim that "metalworkers are only humans." It reveals that many among the Israelites seemingly granted the metalworkers a semi-divine dimension.

\section{Metallurgy as YHWH's Essential Attribute}

Some attributes of YHWH in the Bible confirm the metallurgical background of his worship. The first concerns his appellation. YHWH is a name formed on the Semitic root hwy, which signifies "to be," but also "to blow." Though the first etymology is advanced in Ex 3:14, scholars today assume that the name YHWH designates him as "the blower" (Knauf 1984; Van der Toorn 1999, 916). They generally conclude a storm-god identity of the god of Israel, but blowing is a necessary action in metallurgy, not in rainmaking. Furthermore, the appellation "the blower" fits especially the metallurgical activity of YHWH described in Isa 54:16.

\section{The Sites of Origin}

Further observations corroborate this interpretation. The first concerns the southern origin of YHWH, which is resumed in Deut 33:2a: "YHWH came from Sinai and glowed (zārah) from

4 A grammatical ambiguity concerning the identity of the subject, YHWH or the metalworker, and of the verbs describing the metallurgical activity, even strengthens the collaboration between them.

5 As with Aaron in the episode of the golden calf (Exodus 32), this verse suggests that they did not worship the statuettes they produced for others. 
Seir upon us; he shone forth (hôpî́ $a$ ) from Mount Paran." Today, it remains challenging to precisely locate these sites. However, it is noteworthy that these three regions all encompass areas of copper production active from the Bronze Age (and even before): the mountainous region of Seir probably includes the Faynan mining area in middle-Arabah. ${ }^{6}$ The mountainous region of Sinai (South Peninsula), which is attached to YHWH's revelation, encloses the broad mining areas of Bir Nasib/Wadi Megara/Serabit el Khadem. Paran's wilderness is generally located in the interface between the eastern Negev and Sinai (Axelsson 1987, 59; Dozeman 1998, 39-40), a region including the mining copper areas of Beer-Ora, Yotvata, and Timna in Southern Arabah. The reference to the Timna mining area is especially relevant if, as already suggested, the toponym Eil-Paran (Gen 14:6) is located in the region of Eilat (Bar-Deroma 1964, 118) (see figure 1).

The oracle in Zech 6:1-5 reveals that the link between the mining areas and the regions of origin of YHWH is not fortuitous. In this vision, the prophet describes YHWH dwelling among mountains of copper: "Again I lifted my eyes and saw, and behold, four chariots came out from between two mountains. And the mountains were mountains of copper" (Zech 6:1). Verse 5 clarifies that the four chariots materialize out of the four winds emanating from the copper domain of YHWH. This oracle supports not only the origin of YHWH from metallurgical areas but also the interpretation of the name YHWH as "the blower" and its metallurgical context of meaning.

\section{The Sinai Covenant}

In Ex 19:16-19, YHWH's revelation at Sinai is accompanied by an earthquake, smoke, and fire. Scholars have long identified the volcanic character of this theophany (see Dunn 2014, 388-97 for review). The description of the event in Deuteronomy confirms this view. There, the divine presence is even associated with a lake of molten lava on the top of the mountain: " ${ }_{11}$ And you came near and stood at the foot of the mountain, while the mountain burned with fire to the heart of heaven, wrapped in darkness, cloud, and gloom. ${ }_{12}$ Then YHWH spoke to you out of the midst of the fire. You heard the sound of words, but saw no form; there was only a voice" (Deut 4:11-12). ${ }^{7}$

This description is intriguing because no volcanism is attested in Sinai during that historical period. However, a parallel exists between lava flowing from an active volcano and molten slag released from a furnace at work. In Antiquity, this homology transformed volcanism into a marker of the presence and activity of the god of metallurgy (e.g. Vulcain, Hephaestus). This link is, furthermore, specific because no other human activity could melt stone in Antiquity. The Exodus 19 description of Sinai theophany confirms this interpretation by likening the volcanic eruption with the activity of a furnace: "Now Mount Sinai was wrapped in smoke

$6 \quad$ Most scholars (and biblical atlases) locate Seir in the mountain area eastward of Arabah, based on Edom and Seir equivalence in the Bible. The toponym Seir ("heary") given to these mountains might account for the exceptional presence of a natural forest on this mountain located in a desert area. This contrasts with the toponym Har Halaq ("bald mountain") given to the desert mountain positioned in the Negev, on the west side of the Arabah valley. Bartlett (1989, 41-44; followed by Edelman 1995, 8) located Mount Seir westward of the Arabah valley, assuming that its association with Edom reflects a migration of the Edomites to these regions. But even in this case, Axelsson $(1987,4)$ includes the Arabah valley (and its mining areas) in the Seir mountainous region.

7 See Dunn (2014) for a review of the volcanic interpretation of Sinai theophany both in Exodus and in Deuteronomy. For Graham Davis $(2008,65)$, "It is hard to escape the conclusion that verses like Exodus 19.18 and Deuteronomy 4.11 suggest a volcanic eruption." 


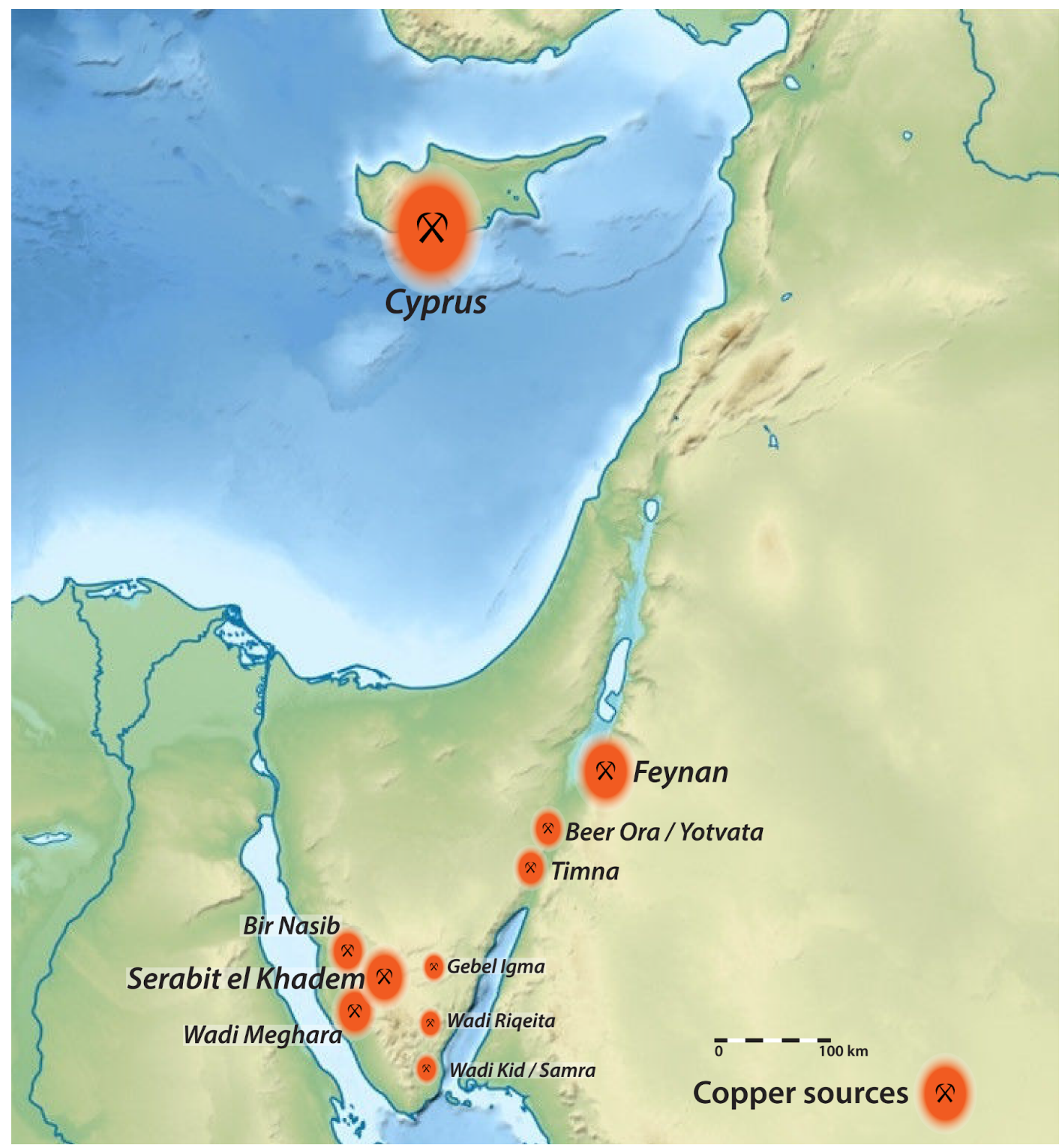

Figure 1 The copper mining areas in activity (Bronze Age and/or Iron Age) in the Southern Levant and its periphery. 
because YHWH had descended on it in fire. The smoke of it went up like the smoke of a furnace, and the whole mountain trembled greatly" (Ex 19:18).

The description of volcanism at Sinai does not reflect any geological event. It was probably introduced to demonstrate that the god acknowledged for his power of melting stone, the god of metallurgy, struck an alliance with the Israelites. This volcanic marker is especially welcome here because the Israelites, unlike the Qenites, are not a people of metalworkers. The non-trivial claim that YHWH made a covenant with the Israelites therefore finds material support in the volcanic representation of the Sinai theophany, volcanism being an attribute attached explicitly to the god mastering the metallurgical processes.

\section{Kābôd-YHWH}

The expression kābôd-YHWH is traditionally translated as "glory of YHWH," and approached as a reference to the abstract notion of divine magnificence. Today, however, some scholars understand it as a technical term describing a fiery reality (Collins 1997, 580-84; Kutsko 2000, 80). At Sinai, kābôd-YHWH looks like a physical reality seen by the Israelites at Sinai following the volcanic eruption: "Now the appearance of kābôd-YHWH was like a devouring fire on the top of the mountain in the sight of the people of Israel" (Ex 24:17). The same materiality of kābôd-YHWH emanates from the description of the Sinai theophany in Deuteronomy: "And you said, 'Behold, YHWH our God has shown us his kābôd and greatness, and we have heard his voice out of the midst of the fire'" (Deut 5:24a). This association of kābôd-YHWH with volcanism, and especially with the crater, invites us to interpret it as the pale yellow radiance emanating from molten lava (Amzallag 2015b). The luminous and fiery nature of $k \bar{a} b o ̂ d-Y H W H$, as well as its association with the liquid element, corroborates this view. If so, $k \bar{a} b o ̂ d-Y H W H$ should not be restricted to molten lava. It also concerns the radiance emanating from molten slag, molten metal, and even the light of the sun (e.g. Isa 59:19; Ps 84:12), because the celestial luminary was frequently envisioned in Antiquity as a bulk of molten metal (Sauneron and Yoyotte 1959, 38; Kristiansen and Larsson 2005, 294-96).

\section{The Copper Altar}

An oracle from Isaiah curiously identifies the Jerusalem temple as the furnace of YHWH: "Declaration of YHWH, whose fire ('ûr) is in Zion and whose furnace (tannûr) is in Jerusalem" (Isa 31:9b). This claim is frequently interpreted as an expression of the burning anger of YHWH against Assur and further enemies (e.g. Watts 1985, 479). However, the claim here refers to something constantly present in Jerusalem, rather than occasional wrath, so the literal meaning is preferable. Likening the temple of Jerusalem to a divine furnace indicates that the religion of Israel preserved substantial elements of YHWH's metallurgical background at the time this oracle was composed.

This Isaiah claim is not unique in the Bible. The book of Ezekiel points to a link between the divine presence in the temple of Jerusalem (Ezekiel 10) and in the celestial universe (Ezekiel 1), both milieus being described in almost the same terms. Interestingly, the first Ezekiel vision (Ezekiel 1) describes the celestial throne of YHWH as a universe of fierce fire (vv. 4, 13, 27), radiance (vv. 13, 27-28), glowing coals (v, 13), and blowing wind (vv. 20-21), all associated with a circular structure (v. 27). This representation of the celestial universe is similar to that encountered in the vision of the celestial universe in Daniel. There, the prophet envisions 
this divine domain as a fiery environment from which a scorching molten matter flows (Dan 7:9-10). Both descriptions fit the representation of the celestial universe as a furnace at work.

The description of a material called hašmal in this celestial milieu, in Ezek 1:4, supports this interpretation. The term hašmal is a hapax, but the homolog terms from cognate languages designate both "amber" and "gold alloys" (Driver 1951; Bodi 1991, 82-90). In Ezek 1:4, hašmal is described as within the fire, from where it radiates intensely. The interpretation of hašmal as "amber" is inadequate here, because this fossil resin emits dark smoke instead of brilliant light once set amid glowing ambers. In these physical conditions, and accounting for the intense radiance emanating from it, hašmal probably designate a metal in molten state here. Consequently, the celestial counterpart of the Jerusalem temple was apparently approached as a fiery furnace, too. This conclusion invites us to look for a metallurgical symbolism in some of the artifacts from the Jerusalem temple, such as the sea of copper, the columns of copper of 59 tons each, and the copper altar.

This latter artifact is extremely rare in the ancient Near East, a feature suggesting that it has a special significance in the worship of YHWH. In Exodus, the copper altar is also called "the altar of burnt-offering" (Ex 30:28; 31:9; 35:16; 38:1; 40:6, 10, 29). No similar reference exists for any other type of sacrifice. This suggests that the copper coating of this altar was especially designed for the sacrifices involving the whole combustion of the animal (burnt offerings). Unlike all the other sacrifices, a burnt offering requires a temperature close to $1000^{\circ} \mathrm{C}$ for the whole transformation of bones into ashes. At these physical conditions, the metal coating the altar has a temperature close to its melting point. It glows with an orange light, the thermal radiance identified with kābôd-YHWH (see above). Consequently, the copper coating transforms the altar into a revelator of the divine presence during the combustion of the burnt offering.

The importance of copper is confirmed in the inauguration of the copper altar (Leviticus 9). There, Moses ensures that following his instructions concerning the sacrifice of burnt offerings will stimulate YHWH's theophany: "And Moses said, this is the thing that YHWH commanded you to do, that kābôd-YHWH may appear to you" (Lev 9:6). The construction of the copper altar from wood (Ex 27:1) explains how it could be transported throughout the wanderings of the Israelites. However, this is unrealistic because wood cannot resist the temperatures reached during the combustion of burnt offerings. But a stone altar coated with copper was set in the courtyard of the Jerusalem temple (1 Kgs 8:64; 2 Kgs 16:14-15; Ezek 9:2; 2 Chr 1:5-6), and its temple counterpart likely inspired the copper altar of the Tabernacle. We may conclude that, in ancient Israel, the copper altar was the furnace-like artifact that materialized the divine presence in the temple through the emission of thermal radiance. The Jerusalem temple is the only attested instance of a copper altar in YHWH's sanctuary in ancient Israel. It is why this artifact symbolically transforms the Jerusalem temple into the furnace of YHWH, as claimed in Isa 31:9.

Further observations may be added concerning the metallurgical dimension of ancient Yahwism in the Bible (see Amzallag 2013, 2015a, 2016, 2018a, 2019a; Amzallag and Yona 2017). But those discussed above are enough, in my view, to identify a substantial metallurgical background in ancient Yahwism. This reality supports the Qenite hypothesis of the origin of Yahwism. The furnace symbolism of the Jerusalem temple also reveals that the metallurgical background of ancient Yahwism did not rapidly disappear in ancient Israel. 


\section{Arabah as the Hearth of Yahwism}

Most of the ancient Israelites were farmers and breeders. Thus, we expect their patron god to be identified with storm, rainfall, and crop vitality rather than metallurgy. This discrepancy may explain why the cult of Baal, more appropriate to the Israelite way of life, well survived the rise of YHWH in ancient Israel. So why did Israelites transform YHWH into their patron deity?

\section{The Copper Industry in the Southern Levant}

The emergence of Israel, in the Early Iron Age, is concomitant with the development of the copper industry in the Arabah. The peak of heavy metal pollution in soils and the accumulation of up to 80,000 tons of slag, mainly between the twelfth and ninth centuries BCE, reflect the outstanding importance of this industry (Levy et al. 2004; Grattan, Gilbertson, and Hunt 2007; Levy 2008). The copper produced was exported through the Northern Sinai route (via Kadesh Barnea), the northern Negeb road joining the Mediterranean harbors, the King's highway reaching the north, the Jezreel road linking the Jordan valley with the Carmel area, and the Phoenician maritime trade (see figure 2). The transportation and trade of metal had a profound influence on the whole Southern Levant. It stimulated a process of sedentarization and the development of agriculture alongside the roads of trade. It also stimulated the construction of strongholds for the protection of the roads and the caravans, including an eastern peripheral defensive system protecting the road of transportation against plundering by the Arabian nomads (Finkelstein, Koch, and Lipschits 2011; Mattingly 2015).

The vocation of the new settlements emerging around these roads was not only the sustenance of the caravans transporting copper from the Arabah. The discovery of metallurgical installations in many of them reveals their involvement in purifying, alloying and casting the metal produced in the Arabah. The metallurgical activity attested in the cities of Tel Masos (Tebes 2003, 69, 74, 2006, 85; Master 2014, 90), Beer Sheba valley (Herzog and Singer-Avitz 2004; Sergi 2013), Gath (Sergi 2013, 228; Ben-Yosef and Sergi 2018, 469), and the region of Mahanaim/Deir Allah (Kempinski et al. 1983, 21; Veldhuijzen and Van der Steen 1999, 195, 198) is a factor of importance in the development of these cities in the early Iron Age (see figure 2). This extension of the metallurgical activity from the Arabah to the whole Southern Levant apparently reflects the limitation of wood for fuel in the area of copper production. This constraint limited the activities performed in the mining areas to smelting, so that further sites localized on the roads of transportation were left with the opportunity to perform the further stages, purification, alloying, and transformation of the metal.

It is why the rise of the copper industry from the Arabah in the early Iron Age became a substantial source of wealth and of sedentarization in the whole Southern Levant. Metallurgy is therefore a central actor in the emergence of new nations in this region from the twelfth century BCE. The nation of Edom set up around the Arabah copper industry (Levy et al. 2004; Tebes 2007, 81, 85-86; Lipinski 2006, 381). The birth of Moab and Ammon accompanied the process of sedentarization around the King's highway and the defense of the production, transportation, and trade of copper (Finkelstein, Koch, and Lipschits 2011, 145; Tyson 2014, 186-93). This reality also influenced the birth of Israel. Many northern tribes (Asher, Zebulun, Naphtali, Issachar, Reuben, Gad) are located around the Jezreel road of transformation, trade, and transportation of copper from the King's Highway to the Mediterranean harbors (Van der Steen 1996, 63; Mazar 2003, 88). The process of sedentarization and development alongside 


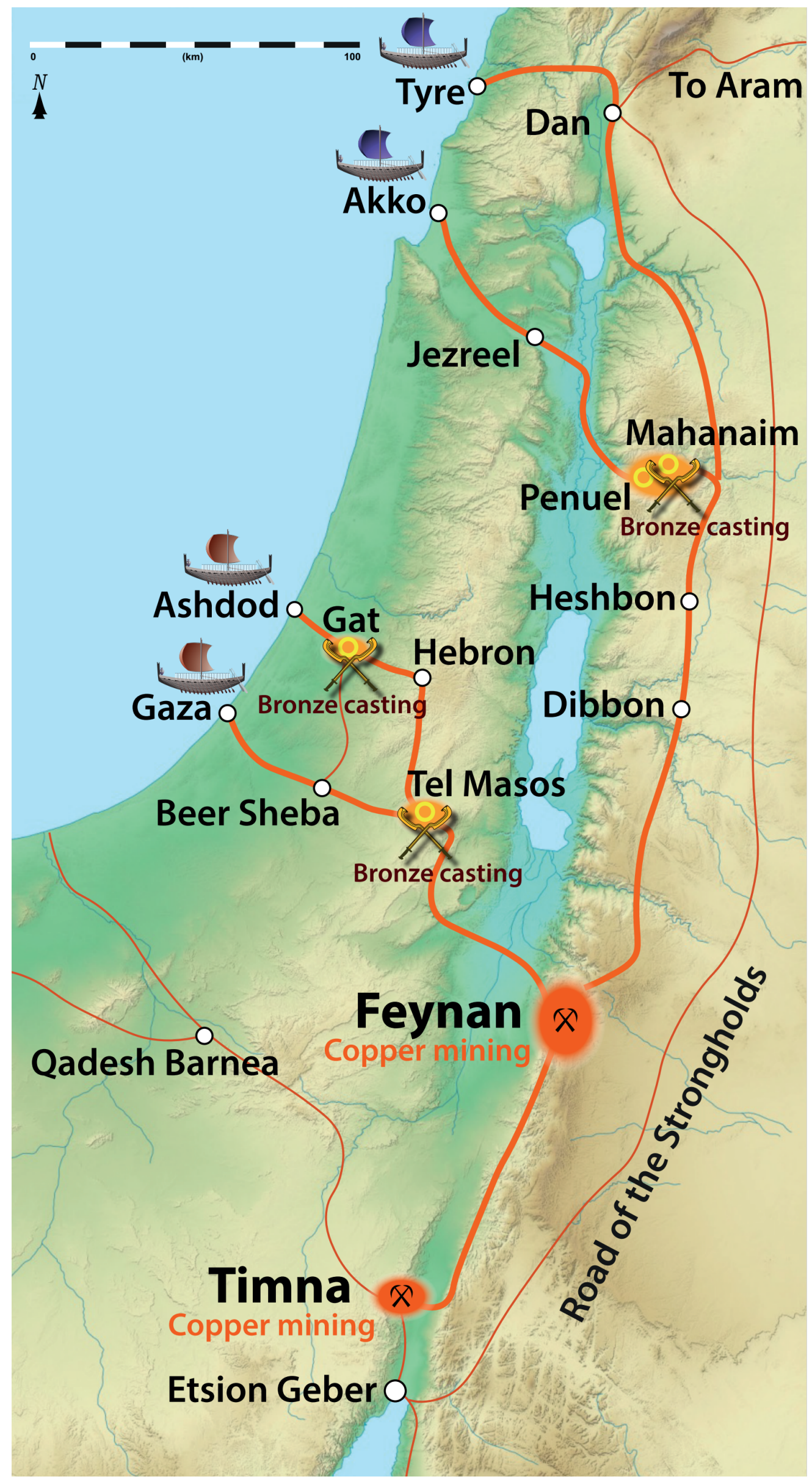

Figure 2 The copper production network in Southern Levant in the Early Iron Age. 
the Jezreel road was likely similarly motivated as the development of Ammon and Moab, alongside the King's Highway.

Southern Judah and the Philistine cities also developed in close relation with the Negev road of transportation of copper. Many Philistine cities are positioned on the way from the Beer Sheba valley to the Mediterranean shore, and traces of metallurgical activity and of exchange with populations from the Arabah betray their involvement in this network (Martin and Finkelstein 2013; Ben-Yosef and Sergi 2018). The development of the southern hills of Judah is probably a consequence of the increased metallurgical and economic activity of the Beer Sheba valley (Herzog and Singer-Avitz 2004; Sergi 2013). This trend coincides with the development of new axes of transportation and treatment of metals through the Arad valley and the Hebron hills, bringing the metal to the Mediterranean shore through the Shephelah (see figure 2). ${ }^{8}$

The importance of metallurgy in early Israel corroborates some biblical sources relating to the emergence of Israel. The Song of Deborah, one of the most ancient documents in the Bible, apparently refers to the earliest stage of the emergence of Israel. It reports the northern tribes' victory against a coalition of kings fighting for the control on the Jezreel valley and its routes of transportation (Schloen 1993). The preservation of this victory in the Israelite collective memory suggests that the transportation of goods through the Jezreel valley was a factor involved in Israel's emergence.

The nature of the military conflicts in early Israel, the period identified with Saul kingship, supports this conclusion. The book of Samuel reports a Philistine offensive against Israel for the control of the Jezreel valley (1 Samuel 31). This military campaign looks like an attempt to extend Philistine participation in metal circulation to the northern network (Bar 2014, 828). Therefore, it reveals that the Israelites controlled this section of the northern pathway of metal transportation and trade before this conflict.

The book of Samuel also reports a series of military campaigns conducted by Saul against Edom, Amaleq, and the Philistines (1 Sam 14:47-48), all peoples involved in the southern network of trade (Edelman 1988, 254; Finkelstein 1988, 250; Bar 2014, 828-29). If the site of Tel Masos corresponds to the 'ir Amaleq mentioned in the Bible (see Finkelstein 1988, 243 for review), the military campaign of Saul against this city (and other Amaleqite installations, see 1 Sam 15:5-7) was clearly targeted against the central station of the southern network of metal transportation and trade. ${ }^{9}$ In this context, the Saul war against Edom may even be interpreted as an attempt to control not only the paths of transportation but even the areas of production of copper (Brooks 2005, 114; Bar 2014, 829). These indications confirm that the network of production, transportation and trade of copper was of central economic importance in the early Israelite period. Therefore, it may justify the transformation of YHWH into the patron deity, even though most Israelites were not directly involved in the production, transformation, or trade of copper.

\section{The Worship of YHWH Among Nations}

Israel was only one among the many nations benefitting from the renewal of copper production. Consequently, if metallurgy is a central factor conditioning the cult of YHWH in ancient

8 This is evidenced by the discovery of Qurayyah ware in Hebron and other settlements from the Judah highlands (see Tebes 2013, 319).

9 It also suggests that the decline of the city of Tel Masos, in the tenth century, was apparently a consequence of the Israelite attempt to control the southern network of trade of metal (Tebes 2003, 75, 2017, 173). 
Israel and Judah, we may also expect a parallel situation in the other South Levantine nations emerging concomitantly with Israel. Though this is not explicitly acknowledged in the Bible, many indications suggest it.

- The oracle in Amos 9:12 mentions Edom at the head of a cluster of nations "calling YHWH by his name," leaving no doubt that nations other than Israel worshipped YHWH and that Edom was at their head. Edom's privileged situation fits its leading position in the copper industry.

- In Deut 2:5, we read that YHWH ascribed his holy mountain, Mount Seir, as an eternal possession to the Edomites. It confirms the status of Edom as leader of YHWH's worship in the Early Iron Age.

- The second chapter of Deuteronomy forbids Israel from attacking its neighbors (Edom, Moab, Ammon) because YHWH is involved in their emergence exactly as with Israel (Deut 2:5, 9, 19). This means that YHWH was committed not only to Edom, the nation organized around the production of copper, but also to all the other nations involved in the network of trade, transportation, and transformation of the metal.

- The book of Genesis identifies Abraham as the hero renewing the alliance with YHWH in the Southern Levant. This alliance clusters all the newly emerging nations and confederations benefitting the metallurgical activity in Southern Levant: Abraham is the godfather of Israel, but also of Edom, Ammon, Moab, and the desert tribes from the Negev. Though the Philistines are of foreign origin, they concluded an alliance with Abraham in the name of YHWH (Gen 21:23-32). Consequently, they also integrate what the book of Genesis portrays as the Abraham confederation of peoples blessed by YHWH.

- The oracle from Amos 9 confirms the involvement of YHWH in the emergence of peoples other than Israel at the Early Iron Age: "Did I not bring up Israel from the land of Egypt, and the Philistines from Caphtor and the Arameans from Kir?" (Amos 9:7b). Like the Philistines, the Arameans participated in the network of trade and transportation as a northern extension of the King's highway (see figure 2).

- The story of Balaam (Numbers 22-24) confirms that non-Israelite prophets of YHWH existed in the Southern Levant in the Early Iron Age. It also reveals that non-Israelite people (here the king of Moab) appointed these prophets for consulting $\mathrm{YHWH}$, just as the kings of Israel did (e.g. Achab, 1 Kgs 22:5-6).

The absence of theophoric names with YHWH, out of Israel, apparently challenges the idea of the widespread prestige of this deity in the Southern Levant. But this silence might have another explanation. It may reflect a situation of esoteric worship of YHWH outside of Israel. This presumption finds support in the Bible. For example, we learn that before the birth of Israel, the 'sons of Jacob' acknowledged YHWH (called "the God") and feared him (Ex 1:17). They also identified the metalworkers as his emissaries (Ex 4:1-5), but they ignored his original name. The secret dimension of YHWH's identity emanates from the question addressed by Moses to YHWH concerning the revelation of his name: "Then Moses said to God, 'If I come to the people of Israel and say to them, 'The God of your fathers has sent me to you,' and they ask me, 'What is his name?' what shall I say to them?"' (Ex 3:13). The esoteric dimension of YHWH's worship is confirmed in Isaiah: "Verily you are a hidden God 
('êl misttattèr); O God of Israel, the savior" (Isa 45:15). In Isaiah, too, the prophet invites other peoples, here the Phoenicians from the Mediterranean colonies, to worship YHWH openly, in the Israelite fashion: "Therefore give glory to YHWH in light (bā'ürîm); In the coastlands of the sea, give glory to the name of YHWH, the God of Israel" (Isa 24:15). Consequently, it seems that an open, official cult of YHWH is the novelty introduced by the Israelites in the Southern Levant. It reflects the transformation of YHWH into patron-god of the Israelites at a time when he remained a great god of esoteric nature for all the other nations from Southern Levant.

\section{The Singularity of Israel}

Until now, we have assumed that the Israelites differed from their neighbors in their worship of YHWH, and we looked for the origin of such a religion. But in light of the present considerations, the question centers around the origins of the transformation of an esoteric religion into the official worship of YHWH, which occurred in ancient Israel.

Let us examine the map of the emergence of nations in the Southern Levant (see figure 3 ). It reveals their organization around the main roads of transportation of copper from the middle Arabah, the region of Faynan. Most of these regions are under the influence of Edom, the nation controlling the production of copper in Faynan and its hinterland. ${ }^{10}$ This influence includes Israel. Juan Tebes $(2017,171)$ stresses "the role of early traders coming from the south, such as Midianites, Kenites and Amalekites, in the diffusion of Yahwism to the ancient Israelites settling in Central Canaan."

Indeed, the biblical genealogies reveal a substantial involvement of southern clans of metalworkers affiliated to Edom (Qenites, Qenizites, Jerahmaelites) in the constitution of the Judah (Axelsson 1987, 179; Knoppers 2001, 23-28; Blenkinsopp 2008, 146-49). The Qenizite leadership over Judah, expressed through the figures of Caleb (Num 13:6; 32:12) and Othniel (Jos 15:13; Judg 1:12-16), confirms the central importance of metalworkers in the emergence of Judah. This Edomite involvement is sometimes interpreted as the retrojection into a mythic past of the migration of Edomites in Judah in the Persian period (e.g. Knoppers 2001). For many authors, however, these reports account for the critical importance of an Edomite-Qenite component originating from the south in the emergence of Judah and in the introduction of the worship of YHWH in this tribe (Axelsson 1987, 179; Blenkinsopp 2008, 148; Tebes 2017, 172).

The same Edomite influence may be identified in the emergence of early Israel and its worship of YHWH. For Joseph Blenkinsopp $(2008,150)$, "the narrative traditions about JacobIsrael and Esau-Edom leave us in no doubt that the origins and the destiny of Israel were also inextricably bound up with those of Edom." Egyptian documents from the thirteenth century relate the existence of a toponym Yah'qub'ilu (Jacob-El) apparently located in SeirEdom (Knohl 2017, 482-83). From these findings and their biblical parallels, Israel Knohl (2017, 484) concluded that a clan of nomads under the cultural and religious influence of Edom-Seir moved to Canaan in the early Iron Age and introduced the worship of YHWH there.

10 This religious primacy is suggested in Genesis by the blessing Isaac reserved for Esau, the father of Edom: "Be lord over your brothers, and may your mother's sons bow down to you; Cursed be everyone who curses you, and blessed be everyone who blesses you!" (Gen 27:29). 


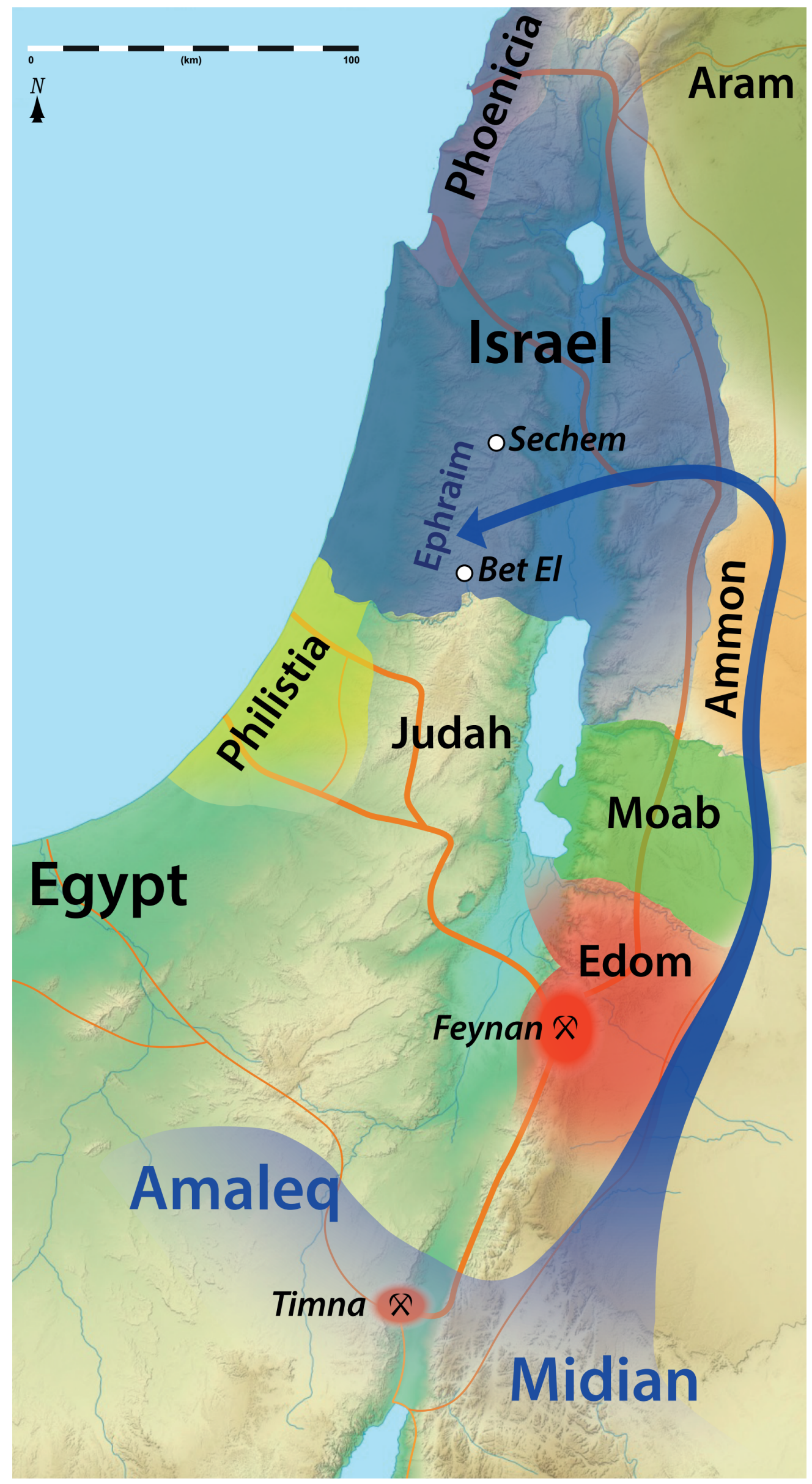

Figure 3 The emergence of new nations in Southern Levant in the early Iron Age. 


\section{Ephraim and the Epos of Exodus}

The rise of Israel integrates into the general scheme of the emergence of nations in the Southern Levant during the early Iron Age, based on the local population's sedentarization around the roads of transportation of metal. This process is stimulated by the large-scale cooperation between clans involved in the conveying, trade, and transformation of metal and the need to collaborate to protect caravans and organize logistical support to the transportation. Likely, the installation of metalworkers along these pathways was probably a factor driving cultural cohesion and religious unity.

A singularity is observed, however, concerning the rise of Israel. There, in parallel with the settlement around the Jezreel valley, we observe a sedentarization process in the highlands of Samaria. This phenomenon corresponds more or less with the development of the tribe of Ephraim and a part of Menasseh (see figure 3). This process was distant from the networks of metal transportation and was therefore likely independent of them. Nevertheless, the frequent designation of the whole of Israel (northern tribes) as Ephraim, in some biblical sources, ${ }^{11}$ suggests that the highlands of Samaria rapidly became the core of Israel's identity. The relative isolation of this region from the metallurgical networks authorized the development of a cultural identity not subordinated to the Edomite influence and distinct from that of all other nations newly emerging in the Southern Levant.

The material culture of the population sedentarizing in southern Samaria denotes a cultural influence from the southern desert areas (Rendsburg 1997, 437; Sparks 2007, 595-97, 606; Faust 2015, 467, 475-78, 2016, 170). Therefore, it seems that a nomad population originating from the desert areas then settled in the region more or less identified with the tribe of Ephraim. This feature is especially interesting in light of Ephraim's leadership (through the biblical figure of Joshua) in the conquest of the Promised Land. Consequently, the biblical epos of exodus and conquest leading to Israel's birth might carry the memory of the migration of nomads originating from the desert areas of Negeb, Sinai, and/or northwestern Arabia. It reflects their installation in southern Samaria, in the early Iron Age, independently of the networks of production, transportation, and trade of copper. These observations, and especially the identification of the biblical epos of exodus and conquest with Ephraim, suggest that this tribe might have promoted the singularities of the Israelite Yahwism regarding the classical approach to this deity in Southern Levant.

\section{The Amaleqite Connection}

In the Bible, the tribe of Ephraim displays affinities with Amaleq, the nomads living in a vast desert area, including northwestern Arabia, Araba, Negev, and Northern Sinai (Num 13:29; 1 Sam 15:7; 30:10-21). Their kinship is announced in the Song of Deborah ("The Ephraimites have their root in Amaleq", Judg 5:14). The existence of a Mountain of Amaleq in Ephraim's territory (Judg 12:15) corroborates this claim, and is why scholars assume that the tribe of Ephraim is a branch of Amaleq, who migrated, conquered, and settled in the Samaria highlands, a region almost uninhabited at the end of the Bronze Age (see figure 3) (Cazelles 1974, 236; Smith 2001, 145; Benz 2016, 375).

The Amaleqites were apparently involved in the southern network of transportation, work, and trade of copper from the Arabah valley to the Mediterranean shore. This is especially true

11 e.g. Isa 7:17; 11:13; 17:3; 28:1; Jer 7:15; 31:18,20; Hos 4:17; 5:3,9-14; 6:4,10; 7:11; 9:3; 11:8 and Zech 9:10. 
if the site of Tel Masos corresponds to the city of Amaleq mentioned in the Bible. But the link between Amaleq and the metallurgical traditions of the Southern Levant probably existed before the Iron Age. This early link is suggested by the reference to Amaleq in the genealogy of Edom and Seir mentioned in Genesis 36. The composition of the book of Genesis dates from the Persian period, so that the insertion of the genealogy of Edom is sometimes considered to reflect a post-exilic reality (Hoekveld-Meijer 1996, 12). Nash (2018) even suggests that this genealogy expresses the wish to differentiate the Judahite lineages from the Edomite, after the migration of these latter in Judah. However, the interrelation between the names mentioned in this genealogy and toponyms indicates that this genealogy elaborates on a historical background many centuries old (Blenkinsopp 2008, 149).

Genesis 36 identifies Amaleq as the son of Timna, the concubine of Elipaz the Edomite (Gen 36:12). Amaleq displays, therefore, a double affiliatio, as on the one hand, he is the son of Elipaz, the firstborn of Esau-Edom (Gen 36:10). Through this affiliation, Amaleq integrates the emergence of Edom in the early Iron Age and the production of copper conditioning it. On the other hand, Amaleq is the son of Timna and the grandson of Seir (Gen 36:20,22). This integrates this tribe within the ancient population living in the Arabah valley before the rise of Edom (Axelsson 1987, 68). ${ }^{12}$ Furthermore, Timna's status of concubine, instead of wife, of Elipaz suggests Amaleq's relative autonomy regarding the nation of Edom. This conclusion finds support in the geography of the Arabah area if Timna associates Amaleq with the southernmost district of copper production in the Arabah valley. The Timna area of copper production was relatively isolated from the core of the Edomite copper industry (centered on Faynan) and its distribution network. This autonomy might also include a religious dimension, an unusual form of Yahwism attached to Timna and the Amaleqites.

This potential autonomy invites us to devote special attention to the mining site of Timna. Though it remains of secondary importance concerning the copper industry, the site of Timna might reveal information of crucial importance for understanding the emergence of Israel, and especially on the singularities of its theology.

\section{The Findings from Timna}

\section{The Tent Sanctuary}

Beno Rothenberg, the first investigator of the site of Timna, dated the earliest traces of mining and metallurgy to the fifth millennium BCE (Rothenberg 1999b). However, the main metallurgical activity of this site dates to the Late Bronze Age and Early Iron Age. An Egyptian exploitation of copper ore is identifiable from the fifteenth to the fourteenth centuries BCE, but the main metallurgical activity occurred in the Early Iron Age, mainly between the twelfth and tenth centuries BCE (Ben-Yosef et al. 2012). As in Faynan in the same period, the material culture of the metalworkers from the Early Iron Age reflects their local origin (Ben-Yosef 2018). The most exciting findings from Timna, for our purpose, come from a small place located amid the mining area and defined as site 200. In the Egyptian period, it was the location of a sanctuary devoted to Hathor, the Egyptian goddess of mines. Remains of furnaces at the entry of the chapel indicate that cultic metallurgy was practiced there.

This sanctuary underwent a profound transformation around the thirteenth century BCE,

12 This ancientness is confirmed in the Balaam oracle, which considered Amaleq as the earliest nation (Num 24:20). 
when local metallurgy replaced the Egyptian mining activity. The furnaces involved in cultic metallurgy were preserved, but a tent sanctuary substituted the Hathor chapel. This new shrine reused some pillars from the ancient chapel, but not before defacing the Egyptian figures, including that of Hathor (Rothenberg 1988, 150-51, 1999a, 171). Apparently, the indigenous people exploiting the copper resources in the Early Iron Age rejected the Egyptian markers of identity, especially those concerning cultic metallurgy. This detail is interesting for our purpose because it echoes the total rejection of Egypt and its culture visible in Exodus, the epos of the birth of Israel.

This is not the only congruence between the birth of Israel and the transformations observed at Timna. Both occurred at the same period, during the thirteenth to twelfth century BCE. And like the tent sanctuary from Timna, the earliest Israelite sanctuary is a tent of meeting (Ex 33:7-11, apparently already mentioned in Ex 18:7-13, see Amzallag 2019b, 302-3). Almost nothing is revealed about it except the reference to fire and smoke produced near the entry of the tent during the encounter between Moses and YHWH (Ex 33:9-10). This description fits the position of the furnaces used for cultic metallurgy in the entry of the tent sanctuary from Timna (Rothenberg 1988, 192-98, 276-278; 1999a, 149-75, 172). Furthermore, a copper serpent existed in the naos of the tent sanctuary from Timna (Rothenberg 1988, 147 and Plate 11), and a similar artifact is attributed to Moses in the Bible (Num 21:4-9). Its metallurgical connotations emanate from its name, nẹhūšttān (2 Kgs 18:4), a wordplay between nāḥ̄ās ("serpent") and něhōšet ("copper"). The fabrication of this něhūšttān in the Arabah valley (near an area of copper production, see Amzallag 2015c, 114-16) substantiates its metallurgical connotations. The setting of this copper serpent in the Jerusalem temple (up to the Hezekiah reform, see $2 \mathrm{Kgs} \mathrm{18:4)} \mathrm{introduces} \mathrm{a} \mathrm{parallel} \mathrm{between} \mathrm{the} \mathrm{Jerusalem} \mathrm{temple} \mathrm{(=the} \mathrm{furnace} \mathrm{of}$ YHWH) and the Timna tent sanctuary. These observations render the site of Timna important for understanding the emergence of Israel and its worship of YHWH.

\section{The Qurayyah Ware}

In the Early Iron Age, a new type of painted pottery, easily identifiable by its texture and style, appears in the Arabah valley and at a few sites located on the roads of trade and transportation of copper. Its appellation as Qurrayah ware reflects its origin in an oasis located in Northwestern Arabia, in an area corresponding with the biblical land of Midian (see figure 4).

This painted ware, apparently used for ritual rather than domestic purposes, is rare in the Southern Levant yet especially abundant in Timna (Rothenberg and Glass 1983, see figure fig:figure5). Its massive presence at site 200 suggests that it was particularly associated with the worship performed in the tent sanctuary. Consequently, the people who brought this pottery in Timna might have been involved in the renewal of the copper production and the cult of YHWH. By extension, the theological singularities distinguishing Israel from all the other nations in the Southern Levant may reflect a Qurayyah influence on the Amaleqite people from which the tribe of Ephraim emerged.

This premise finds a support in Exodus. By locating in Midian the first YHWH's revelation to Moses and his vocation, this book emphasizes not only the Qenite influence, via the figure of Jethro, but also the importance of the Midianite environment in the formulation of the theological fundaments of early Israel. This Midianite component is the cause of why the Qenite hypothesis concerning the origin of Yahwism is frequently called the Qenite-Midianite hypothesis (see Blenkinsopp 2008 for review). In light of these findings, we may formulate a new hy- 


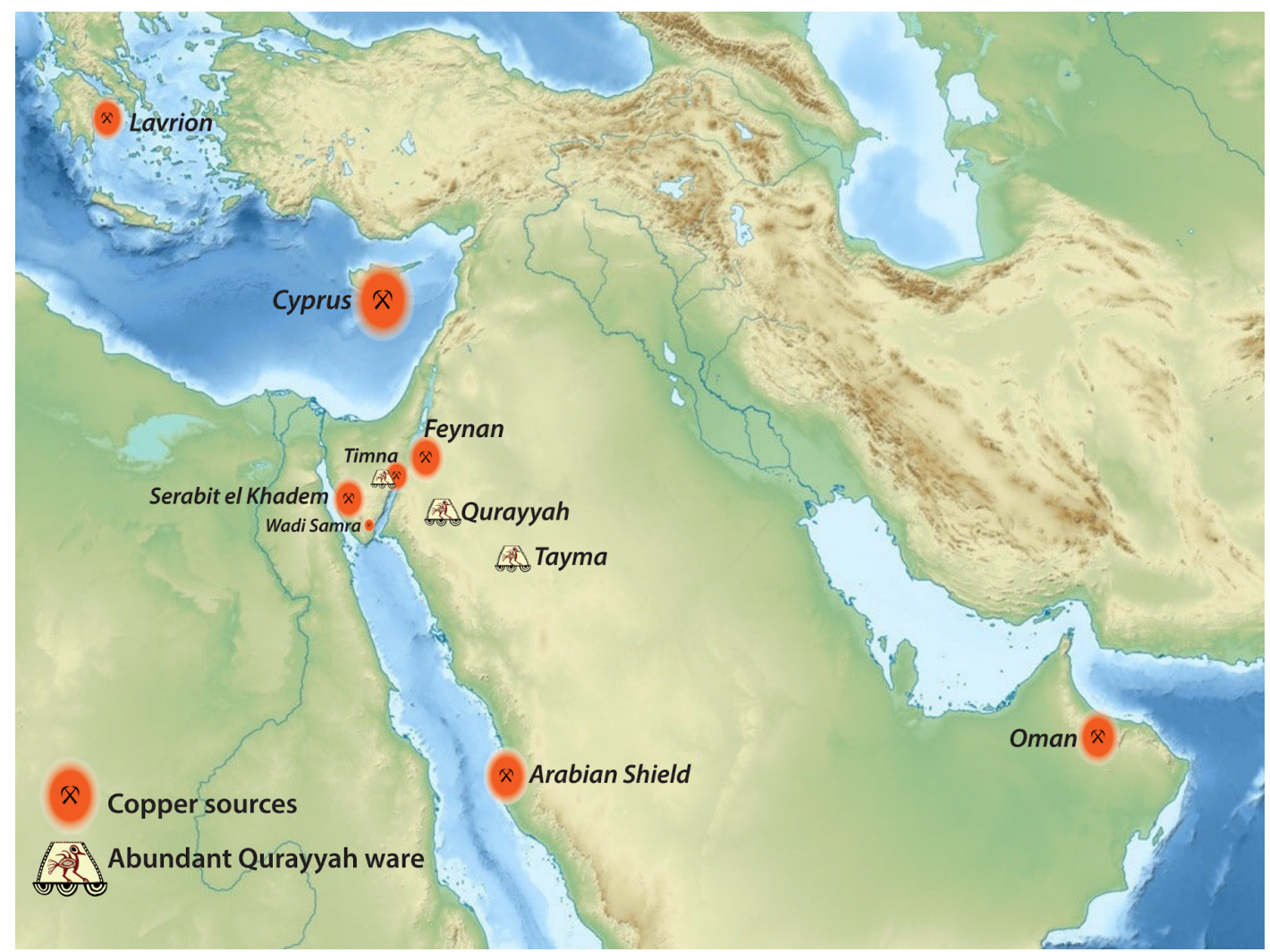

Figure 4 Sites of copper production and of abundant Qurrayah ware in the Iron Age.
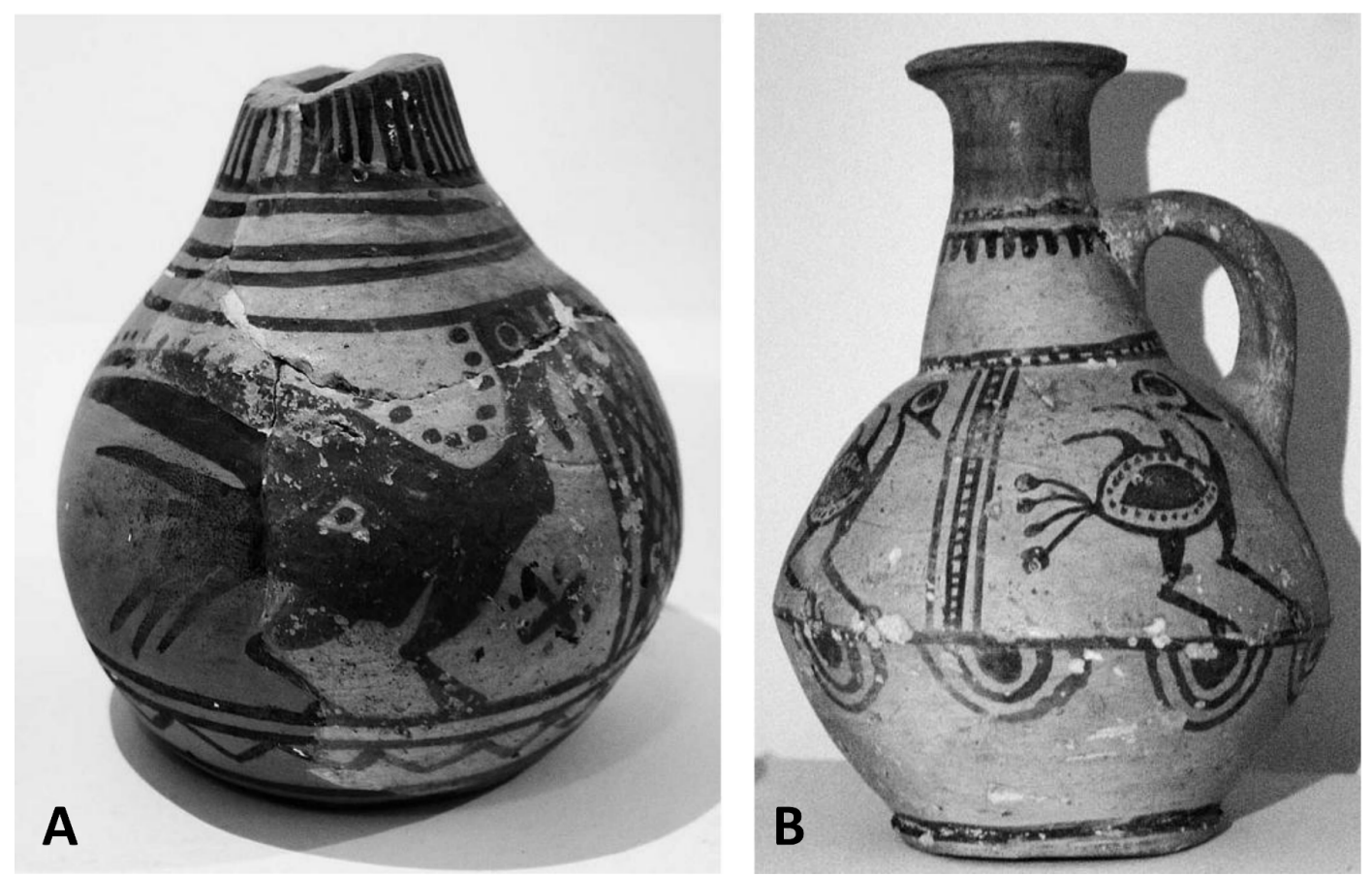

Figure 5 Examples of Qurayyah ware: A. Jar from the sanctuary area of Timna; B. Jar from unknown location in Southern Jordan (Photos from Tebes 2014, 168, 170). 
pothesis: the singularity of the Israelite worship of YHWH might result from the introduction, by the Ephraimites, of a theology conditioned by some Qurayyah/Midianite developments of Yahwism. In this perspective, the Israelite theology differs from other forms of Yahwism in the Southern Levant which lack any substantial influence by this Qurayyah/Midianite form of Yahwism (the Qurayyah ware remaining rare in the core of the Arabah copper industry, Faynan, and its surroundings).

A metallurgical activity, including the production of copper, is attested in the oasis of Qurayyah in the Bronze Age. But the use of arsenic instead of tin for alloying copper, up to the Late Bronze Age, reflects the practice of archaic metallurgy in Qurayyah, largely uninfluenced by the technical developments observed in the ancient Near East at this time (Liu et al. 2015). Consequently, it is tempting to identify this oasis as being one of the sites of preservation of the old metallurgical traditions of the Southern Levant, and of their autonomous development. If this premise is founded, we should expect to find in the Israelite theology some traces of a desert-shaped form of Yahwism reflecting the Northwestern Arabian reality. Here, I intend to briefly examine two examples of such an influence: the assumption of divine intervention in history, and the redefinition of the people of YHWH.

\section{The Assumption of Divine Intervention in History}

The exodus from Egypt is the founding event of Israelite theology. But it is also the fundamental claim supporting the idea of YHWH's active involvement in history. This latter seems to be a theological novelty. The absence of targeted divine intervention before the rise of Israel may be deduced from the lack of supplications to YHWH from the Israelites in Egypt (Exodus 1-2). Also, the fabrication of the Golden Calf for guiding and protecting the Israelites (Ex 32:1) stresses that YHWH's transformation into a patron-deity defending his people is not only unusual, but also difficult to accept. The insertion of this story in Exodus 32, a few chapters after the Sinai Covenant, reflects the confusion and novelties inherent in the transformation of YHWH into the patron-deity protecting the Israelites for a people generally used to addressing YHWH through an intermediate deity (here symbolized by a calf).

The reservation concerning YHWH's ability to intervene did not disappear after the "sin" of the Golden Calf. Rather, it recurs periodically in the phase of wandering. ${ }^{13}$ It even affects Moses, who doubts YHWH's ability to feed the Israelites (Num 11:21-23) or even supply water (Num 20:7-13). The belief in the non-intervention of YHWH is explicit not only in the theological history of Israel but also in the sermons formulated in the late monarchic period. We read in a Zephaniah oracle: "At that time I will search Jerusalem with lamps, and I will punish the men settled on their lees; those who say in their hearts, 'YHWH will not do good, nor will he do ill' " (Zeph 1:12). That this situation virulently condemned in Zephaniah probably does not reflect a lack of consideration for $\mathrm{YHWH}$, because it also finds an expression in the myth of creation. There, the six days of creation are achieved with reference to YHWH satisfied and resting, that is, not intervening in the world (Gen 2:1-3). Consequently, the claim of divine intervention in history is probably a novelty advanced by the Israelite theologians, authorizing them to consider YHWH as the patron-deity of Israel, and supplanting the secondary deities (the emissaries of YHWH) traditionally granted this function. This novelty might be rooted in volcanism, which is of outstanding importance in Israelite theology (Koenig 1966; Dunn 2014; Amzallag 2014). 
In the Bible, volcanism is not only the marker of divine presence at Sinai, but also a privileged mode of action of YHWH. This is revealed in Isaiah 40, for example, where a significant volcanic event is expected to transform the landscape and to reveal YHWH and his overwhelming powers to the earth: " ${ }_{4}$ Every valley shall be lifted up, and every mountain and hill be made low; the uneven ground shall become level, and the rough places a plain. ${ }_{5}$ And kābôd-YHWH shall be revealed, and all flesh shall see it together, for the mouth of YHWH has spoken" (Isa 40:4-5). Volcanism is also recruited for divine interventions of targeted nature. This view is illustrated in Psalm 18 (=2 Sam 22), where a volcanic eruption destroying the psalmist's enemies (vv. 9-10) is the divine response to his supplications (v. 8):

${ }_{7}$ In my distress I called upon YHWH; to my God I cried for help. From his domain he heard my voice, and my cry to him reached his ears.

${ }_{8}$ Then the earth reeled and rocked; the foundations also of the mountains trembled, and quaked, because he was angry.

${ }_{9}$ Smoke went up from his nostrils, and devouring fire from his mouth; glowing coals flamed forth from him.

These verses confirm that volcanism was regarded both a theophany and a mode of divine action, through the release of hot gases, ash, pyroclasts, and flowing lava from the crater. In Psalm 18, this eruption is even followed by a violent storm (vv. 12-15):

${ }_{12}$ He made darkness his covering, his canopy around him,

Dark water; thick clouds.

${ }_{13}$ Out of the brightness before him

His thick clouds passed, hailstones and coals of fire.

${ }_{14} \mathrm{YHWH}$ thundered in the heavens,

The Most High uttered his voice,

Hailstones and coals of fire.

${ }_{15}$ And he sent out his arrows and scattered them;

He flashed forth lightning and routed them.

${ }_{16}$ Then the channels of the sea were seen,

and the foundations of the world were laid bare

At your rebuke, $\mathrm{O} \mathrm{YHWH}$,

at the blast of the breath of your nostrils.

The reiterated reference to hot gases and their destroying effect in verse 16 suggests that the storm described in vv. 12-15 is an integrative part of the volcanic event. It invites us, therefore, to identify vv. $12-15$ as the description of a volcanic storm: the striking reference to dark water (v. 12) corresponds to the phenomenon of dirty rain in which rainwater mixes with ash; the mix of hail with fire (vv. 13-14) corroborates the mix of pyroclasts of molten lava and hail falling together during a volcanic storm (Franklin 1926, 189; Todesco and Todini 2004; Mather and Harrison 2006, 393).

Wet volcanism is described in so much details in Psalm 18 that accurate observations of the phenomenon must necessarily have inspired it. This geological knowledge cannot originate from the Southern Levant, where volcanism was ignored in the historical period. However, Western Arabia is the site of extensive volcanic activity throughout the last ten thousand years, with an average lag of 200 years between two eruptions (Camp et al. 1987, 489-90). 
Furthermore, volcanoes and flows of lava remain visible long after the outbreak in this hyperarid region, so that the volcanic activity remains traceable long after eruption events. What is more, Qurayyah is located at the extremity of the Northern Arabian volcanic field Harrat al raha. People from this oasis and the adjacent ones were therefore probably well-informed about volcanism and its characteristics. Consequently, the overextended importance of divine volcanism in the Bible (see Koenig 1966; Dunn 2014 for review) is probably a marker of the Midianite/Qurayyah influence on the theology of early Israel.

As mentioned above, volcanism spontaneously transforms into an essential attribute of YHWH due to its homology with metallurgy. Consequently, the volcanic eruptions in the historical period become evidence attesting divine intervention on earth, long after the time of creation. It is why volcanism might be the source of the theological novelty claiming YHWH's intervention on the Israelites' behalf. This theological innovation introduces a dark side, however. It grants YHWH a violent, exploding, and unpredictable character. It transforms the god of Israel into a divine being capable of an overwhelming, blind destruction through the heat of his anger.

\section{The Redefinition of the People of YHWH}

The other fundamental novelty of Israelite theology is the transformation of the sons of Jacob into the people of YHWH. This claim promotes the substitution by the Israelites of the small congregation of metalworkers, independently of any metallurgical skill and practice. This novelty is expressed for the first time a few verses before the Sinai covenant: " ${ }_{5}$ Now therefore, if you will indeed obey my voice and keep my covenant, you shall be my treasured possession among all peoples, for all the earth is mine; ${ }_{6}$ and you shall be to me a kingdom of priests and a holy nation" (Ex 19:5-6a). This linkage with the Sinai covenant and its volcanic expression invites us to examine whether this second theological novelty is also rooted in the Midianite/Qurayyah traditions.

In Exodus, the transformation of Israel into YHWH's people is conditioned by the possibility of divine residence among the Israelites. This linkage is visible through the project of the construction of the Tabernacle (Exodus 25-31), formulated immediately after the gift of the tables of covenant (Ex 24:12-18). The divine reaction to the sin of the Golden Calf confirms this point. This breakdown of the Sinai covenant is immediately followed by a retirement from the Israelites (Ex 33:5), the cancellation of the project of the construction of the Tabernacle (Ex 33:3), and the appointment of a secondary deity (the emissary of YHWH) to protect the Israelites (Ex 33:2) (Amzallag 2019a, 302-4).

Similarities exist between the Tabernacle and the representation of the Garden of Eden in Genesis 2-3 (Stordalen 2008; Wenham 1987, 61; Lanfer 2012, 133). The homology between the sanctuary's Menorah and the tree of life positioned amid the Garden of Eden exemplifies this parallel. It suggests that the Israelite theology may have intended, through the Tabernacle (an idealized representation of the Jerusalem temple), to rehabilitate the status of Adam before the expulsion from the Garden of Eden. In doing so, their legitimacy as people of YHWH even predates the birth of Cain, the Qenites' forefather. If so, the Tabernacle and its Eden symbolism become of central importance for the theological transformation of Israel into the (new) people of YHWH.

This novelty is not easy to advance, however. In the ancient Near East, the divine gardens were located in mountainous areas, and even at high altitude (Van Dyk 2014; Wyatt 2014). 
This renders them difficult to access, non-habitable by mortals, and therefore unable to serve as a basis for the claim of Israel's residence in the divine garden or in its vicinity.

The representation of the Garden of Eden is complex in Genesis 2. On the one hand, the Garden is the source of the main streams flowing across the earth (Gen 2:10-14), so that it is necessarily positioned at an altitude on the cosmic mountain. But the five verses mentioning this mountainous location are inserted in a whole narrative which challenges this geographical position:

- There are no seasons in the Garden of Eden. The mention of Adam and Eve living naked (Gen 2:25) suggests hot weather. The Garden cannot be positioned atop a mountain.

- All the trees of the Garden bear comestible fruits (Gen 2:9, 16). This description fits the representation of the Garden as an orchard positioned at a low altitude rather than a wild forest at elevation.

- There is no vegetation around the Garden of Eden (Gen 2:5), and there is no rain. A hot desert environment surrounds it, which does not fit a mountainous location. It rather describes the Garden of Eden as an oasis.

- The Garden emerges from the discovery of a spontaneous resurgence of water ('ēd) (Gen 2:6) (Tsumura 1989, 120-23). This is precisely the situation for the creation of an oasis.

- Adam is installed in the garden to preserve it (Gen 2:15), that is, to practice horticulture. Crop cultivation is mentioned only after the expulsion from the Garden of Eden. Again, this feature fits its identification as an oasis.

These considerations suggest that the traditional representation of the Garden atop a mountain (Gen 2:10-14) is grafted within its alternative figuration as an oasis. The extremely arid conditions surrounding the Garden of Eden invite us to interpret this myth of origins as an adaptation to the desert environment of an original localization of the garden atop a mountain.

The parallel between the Israelite shrine for divine residence and the Garden of Eden confirms this reference to an oasis. According to Kings (1 Kgs 6:29, 32, 35; 7:36; see also $2 \mathrm{Chr}$ $3: 5)$, the inner and outer walls of the Jerusalem temple were ornamented with palm trees and cherubim. The same singularity concerns the future temple envisioned by Ezekiel (Ezek 41:18-20, 25). The extensive description of this palm tree motif (Ezek 40:16, 22, 26, 31, $34,37 ; 41: 26)$ reflects its theological importance. And exactly as with the Garden of Eden, these ornaments advance the representation of the holy residence of YHWH and the site of divine encounter with Israel as a palm tree oasis. Here again, these observations point to a Midianite/Qurayyah influence on the Israelite theology.

The transformation of the Garden of Eden into an oasis introduces a sweeping change in the man-god relationship. Unlike high mountains, oases are not hostile environments. They are inhabited by people who, by their mere presence, assume a close and permanent relationship with the divine, like Adam in the Garden of Eden. The mere residence in the oasis (the integration into the tribe attached to it) is enough to claim closeness to the divine. This singularity might constitute the theological basis for the Israelites' definition as the people of 
YHWH, through their mere definition as sons of Jacob and their settling around the Tabernacle (Num 2:1-2).

\section{Conclusion}

Devoting attention to the metallurgical background of Yahwism opens a new horizon of investigation. First of all, it provides exclusive support to the Qenite hypothesis. This achievement does not deny the storm-god affinities of YHWH identified in the Bible, but these latter become attributes grafted on an original background of metallurgical nature. The depiction of a volcanic storm, in Psalm 18, is an illustration of how such an accretion process might have occurred.

Furthermore, the metallurgical reality invites us to integrate the rise of Israel into a broad process of development of the Southern Levant fueled by the copper industry. The industry's growth results from a process of cooperation between clans and tribes involved in the transportation, trade, and transformation of copper and the development of agriculture and settlements supporting this activity. It does not mean that the Israelites were all involved in metallurgy, but that they considered this activity to be the driving force of their development, organization, and source of wealth. This reality, once combined with the metallurgical background of ancient Yahwism, clarifies why YHWH sponsors, in the Bible, not only Israel but also of all the other nations newly emerging in the early Iron Age.

In this constellation, the singularity of the religion of Israel, especially the self-definition of Jacob's sons as the people of YHWH, does not reflect any exclusivity of the relationship between YHWH and Israel. It seems instead to result from the influence of a Midianite/Qurayyah form of Yahwism adapted to the hyper-arid volcanic environment of northwestern Arabia. This tradition was the substratum on which a small group of Amaleqites, identified in Israel as the tribe of Ephraim, elaborated its own theology of Exodus and Conquest. Once settled in Canaan, this group apparently diffused this ideology among the tribes initially organized around the Jezreel valley and its metal transportation. This doctrine comprises two main theological novelties. The first is the transformation of the Israelites into the people of YHWH, a feature leading to his public worship. The second is the assumption of YHWH's direct intervention on earth. Both novelties might emanate from a desert-shape form of Yahwism (proto-Midianite) developing in oases from northwestern Arabia.

This proposed representation of the emergence of Israel is only preliminary. It asks for further examination and confrontation with written sources and archaeological findings. But these premises call us to revisit the singularities of the Israelite religion. Instead of in the exclusiveness of the worship of YHWH, the early Israelites probably differed from all their neighbors in their official worship of YHWH at a time where he remained an esoteric deity everywhere else. This transfer of YHWH and his worship to the public domain might be the main contribution of the small group identified as Ephraim, which distinguished Israel from all the other nations of the Southern Levant.

I would like to make a final remark. The production of copper at an industrial level was limited in the Arabah to a short period of about three to four centuries (see figure 6). It began with the collapse of the Cyprus copper industry, at the end of the Bronze Age, and then collapsed itself with Cyprus' resurgence from the ninth century BCE onwards.

This dynamic may explain why, in the Southern Levant, the importance of copper and its cultural components do not find an explicit expression after this period, and why it is 


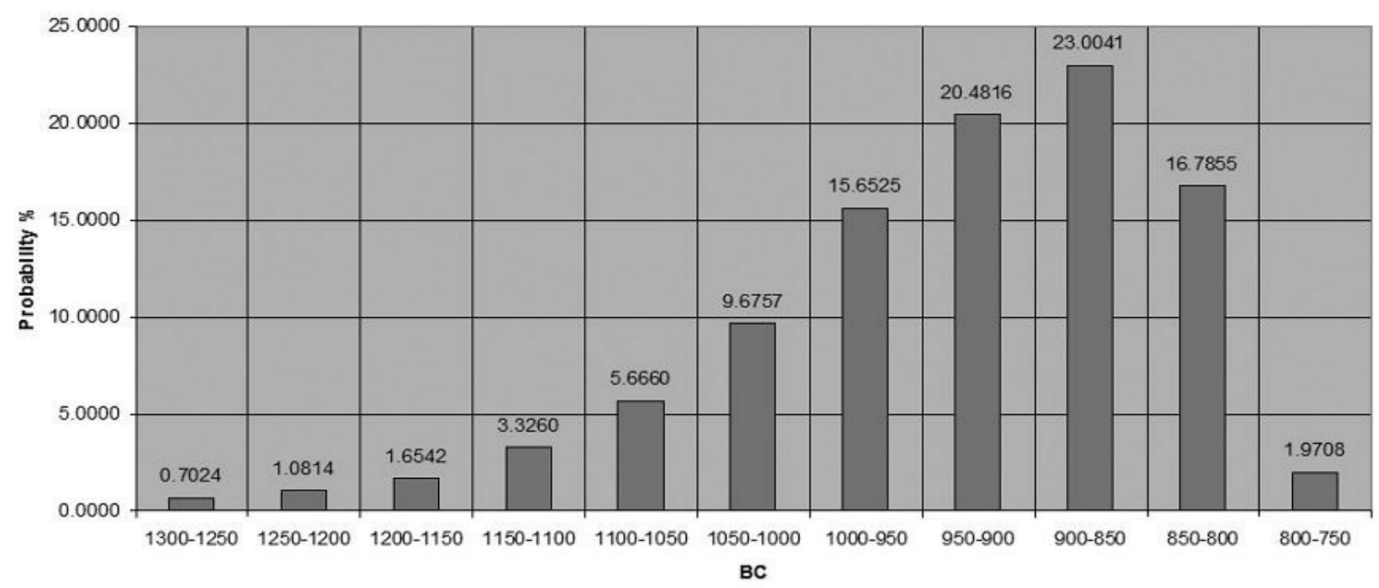

Figure 6 Rate of copper production in Khirbet en-nahas according to the number of radiocarbon determinations* (from Finkelstein 2013, 114, Fig. 31).

so easy today to ignore the cultural importance of metallurgy in this region. However, as shown here, this transient period is of central importance for the emergence of the theology of ancient Israel and the transformation of YHWH into its patron deity. Consequently, we cannot consider the biblical sources referring to this metallurgical dimension as retrojecting their contemporaneous reality onto a mythical past. Rather, references to metallurgy, even in late biblical sources, highlight the survival of a memory of this crucial period.

\section{Acknowledgements}

I would thank Juan Tebes and Christian Frevel for the organization of the conference on The Desert Origin of God: Materiality of Desert Cult in Southern Levant and Northwestern Arabia and YHWH's Emergence (Bochum, 15-17 July 2019) and for the opportunity they gave to me to expose these views. My thanks go also to Juan Tebes and Israel Finkelstein for authorizing me to use their material (photos and graphs in figures 5-6), and to Patrick Jean-Baptiste for the preparation of the figures $1-4$.

\section{References}

Amzallag, Nissim. 2009a. "From Metallurgy to Bronze Age Civilizations: The Synthetic Theory." American Journal of Archaeology 113: 497-519.

- 2009b. "YHWH: The Canaanite God of Metallurgy?" Journal of the Studies of the Old Testament 33: 387-404.

- 2013. "Copper Metallurgy: A Hidden Fundament of the Theology of Ancient Israel?" Scandinavian Journal for the Old Testament 27: 155-80.

- 2014. "Some Implications of the Volcanic Theophany of YHWH on His Primeval Identity." Antiguo Oriente 12: 11-38.

_ 2015a. "Furnace Re-Melting as Expression of YHWH's Holiness: Evidence from the Meaning of Qanna (קנה) in Divine Context." Journal of Biblical Literature 134: 233-52.

. 2015b. "The Material Nature of the Divine Radiance and Its Theological Implications." Scandinavian Journal for the Old Testament 29: 80-96. 
. 2015c. "The Origin and Evolution of the Saraph Symbol." Antiguo Oriente 13: 99-126. 2016. "The Serpent as a Symbol of Primeval Yahwism." Semitica 58: 208-39.

. 2018a. "Beyond Nose and Anger - a Reinterpretation of 7 in YHWH's Context." Revue Biblique 125: 5-28.

— 2018b. "Why Is the Cain Genealogy (Gen 4:17-24) Integrated into the Book of Genesis?" Ancient Near East Studies 55: 23-50.

2019a. "Beyond Prestige and Magnificence - the Theological Significance of Gold in the Israelite Tabernacle." Harvard Theological Review 112: 296-318.

— 2019b. "Moses' Tent of Meeting - a Theological Interface Between Qenite Yahwism and the Israelite Religion." Scandinavian Journal for the Old Testament 33: 296-317.

Amzallag, Nissim, and S. Yona. 2017. "Differentiation of the Qayin Family of Roots in Biblical Hebrew." Semitica 59: 297-332.

— 2018. "The Significance of the Rhetorical Ambiguity in Isaiah 54:16." Old Testament Essays 31: 323-38.

Assis, Elie. 2016. Identity on Conflict. The Struggle Between Esau and Jacob, Edom and Israel. Winona Lake: Eisenbrauns.

Axelsson, Lars E. 1987. The Lord Rose up from Seir. Studies in the History and Traditions of the Negev and Southern Judah. Stockholm: Almqvist and Wiksell International.

Bar, Shaul. 2014. "Saul's Wars Against Moab, Ammon, Edom and Zobah." Old Testament Essays 27: 825-38.

Bar-Deroma, Haim. 1964. "Kadesh-Barne'a." Palestine Exploration Quarterly 96: 101-34.

Barndon, Randi. 2005. "Sparks of Life. The Concept of Fire in Iron Working." Current Swedish Archaeology 13: 1-19.

Bartlett, John R. 1989. Edom and the Edomites. Sheffield: Sheffield Academic Press.

Ben-Yosef, Erez. 2018. "The Central Timna Valley Project: Research Design and Preliminary Results." In Mining for Ancient Copper - Essays in Memory of Beno Rothenberg, edited by Erez Ben-Yosef, 28-63. Tel Aviv: The Sonia and Marco Nadler Institute of Archaeology.

Ben-Yosef, Erez, and Omer Sergi. 2018. "The Destruction of Gath by Hazael and the Arabah Copper Industry: A Reassessment." In Tell It in Gat: Studies in the History and Archaeology of Israel. Essays in Honor of Arenb M. Maeir on the Occasion of His Sixtieth Birthday, edited by Itzhak Shai, Jeffery R. Chadwick, Louise Hitchcock, Amit Dagan, Chris McKinny, and Joe Uziel, 461-80. Münster: Zaphon.

Ben-Yosef, Erez, Ron Shaar, Lisa Tauxe, and Hagai Ron. 2012. "A New Chronological Framework for Iron Age Copper Production at Timna (Israel)." Bulletin of the American Schools of Oriental Research 367: 31-71.

Benz, Brendon C. 2016. The Land Before the Kingdom of Israel - A History of the Southern Levant and the People Who Populated It. Winona Lake: Eisenbrauns.

Berggren, Kristina. 2004. "Homo Faber of Homo Symbolicus? The Fascination with Copper in the Sixth Millennium." Transoxiana 8: 1-7.

Blenkinsopp, Joseph. 2008. "The Midianite-Kenite Hypothesis Revisited and the Origin of Judah." Journal for the Studies of the Old Testament 33: 131-53.

Bloedow, Edmund F. 1991. "Evidence for an Early Date for the Cult of Cretan Zeus." Kernos 4: 139-77.

Bodi, Daniel. 1991. The Book of Ezekiel and the Poem of Erra. Gottingen: Vandehoeck and Ruprecht.

Brooks, Simcha S. 2005. Saul and the Monarchy: A New Look. Burlington: Ashgate. 
Camp, V. E., P. R. Hooper, M. J. Roobol, and D. L. White. 1987. "The Madinah Eruption, Saudi Arabia: Magma Mixing and Simultaneous Extrusion of Three Basaltic Chemical Types." Bulletin of Volcanology 49: 489-508.

Capdeville, Gérard. 1995. Volcanus - Recherches comparatistes sur les origines du culte de Vulcain. Rome: École Française de Rome.

Cazelles, Henri. 1974. "Déborah (Jud. V 14), Amaleq et Mâkîr." Vetus Testamentum 24: 23538.

Collins, C. John. 1997. "Kbd." In New International Dictionary of the Old Testament Theology and Exegesis, edited by Willem A. Van Gemeren, 2:577-87. Grand Rapids: Zondervan Publishing House.

Davies, Graham I. 2008. The Way of the Wilderness. A Geographical Study of the Wilderness Initneraries in the Old Testament. Cambridge: Cambridge University Press.

Dicou, Bert. 1994. Edom. Israel's Brother and Antagonist. The Role of Edom in Biblical Prophecy and Story. JSOT Sup 169. Sheffield: Sheffield Academic Press.

Dozeman, Thomas B. 1998. "The Wilderness and Salvation History in the Hagar Study." Journal of Biblical Literature 117: 23-43.

Dozeman, Thomas D. 2009. Commentary on Exodus. Grand Rapids: Eerdmans.

Driver, Godfrey R. 1951. "Ezekiel's Inaugural Vision." Vetus Testamentum 1: 60-62.

Dunn, Jacob E. 2014. "A God of Volcanoes: Did Yahwism Take Root in Volcanic Ashes?" Journal for the Study of the Old Testament 38: 387-424.

Edelman, Diana. 1988. "Tel Masos, Geshur, and David." Journal of Near Eastern Studies 47: 253-58.

Edelman, Diana V. 1995. "Edom: A Historical Geography." In You Shall Not Abhor an Edomite for He Is Your Brother: Edom and Seir in History and Tradition, edited by Diana V. Edelman, 1-12. Atlanta: Scholar Press.

Eliade, Mircea. 1968. "The Forge and the Crucible: A Postscript." History of Religions 8: 74-88.

Faust, Abraham. 2015. "The Emergence of Iron Age Israel: On Origins and Habitus." In Israel's Exodus in Transdisciplinary Perspective - Text, Archaeology, Culture and Geosciences, edited by Thomas E. Levy, Thomas Schneider, and William H. C. Propp, 467-82. Berlin: Springer.

—. 2016. "The Emergenceof Israel and Theories of Ethnogenesis." In The Wiley Blackwell Companion to Ancient Israel, edited by Susan Niditch, 155-77. Chichester: John Wiley \& sons.

Finkelstein, Israel. 1988. "Arabian Trade and Socio-Political Conditions in the Negev in the Twelfth-Eleventh Centuries B.C.E.” Journal of Near Eastern Studies 47: 241-52.

- 2013. The Forgotten Kingdom. Atlanta: SBL Press.

Finkelstein, Israel, Ido Koch, and Oded Lipschits. 2011. "The Biblical Gilead - Observations on Identifications, Geographic Divisions and Territorial History." Ugarit Forschungen 43: 131-59.

Finnestad, Ragnhild B. 1976. "Ptah, Creator of the Gods: Reconsideration of the Ptah Section of the Denkmal." Numen-International Review for the History of Religions 23: 81-113.

Franklin, George. 1926. "Volcans et dieux." Revue Archéologique 23: 188-249.

Gosić, Milena. 2013. "Metallurgy, Magic and Social Identities in the Ghassulian Culture of the Southern Levant (ca. 4500-4000 BC)." PhD dissertation, Beer Sheba: Ben-Gurion University of the Negev. 
Gosić, Milena, and Itzhak Gilead. 2015a. "Casting the Sacred: Chalcolithic Metallurgy and Ritual in Southern Levant." In Defining the Sacred - Approaches to the Archaeology of Religion in the Near East, edited by Nicola Laneri, 161-75. Oxford: Oxbow.

—. 2015b. "Unveiling Hidden Rituals: Ghassulian Metallurgy of the Southern Levant in Light of the Ethnographical Record." In Copper and Trade in the South-Eastern Mediterranean. Trade Routes of the Near East in Antiquity, edited by Karolina Rosinska-Balik, Agnieszka Ochal-Czarnowicz, Marcin Czarnowicz, and Joanna Debowska-Ludwin, 2537. Oxford: Archaeopress.

Grattan, P. P., D. D. Gilbertson, and C. O. Hunt. 2007. "The Local and Global Dimensions of Metalliferous Pollution Derived from a Reconstruction of an Eight Thousand Year Record of Copper Smelting and Mining at a Desert-Mountain Frontier in Southern Jordan." Journal of Archaeological Science 34: 83-110.

Haaland, Randi. 2004. "Technology, Transformation and Symbolism: Ethnographic Perspectives on European Iron Working." Norwegian Archaeological Review 37: 1-19.

Herzog, Zeev, and Lily Singer-Avitz. 2004. "Redefining the Centre: The Emergence of State in Judah." Tel Aviv 31: 209-44.

Hoekveld-Meijer, Gerda. 1996. Esau - Salvation in Disguise. Kampen: Kok Pharos.

Hundley, Michael B. 2017. "What Is the Golden Calf?" Catholic Biblical Quarterly 79: 559-79.

Kakosy, Laszlo. 1980. "A Memphite Triad.” Journal of Egyptian Archaeology 66: 48-53.

Kempinski, Aharon, Hartmut Rösel, Erel Gilboa, and Th. Stahlheber. 1983. "Area A." In Ergebnisse der Ausgrabungen auf der Hirbet el-Msas (Tel Masos) 1972-1975. Teil I: Textband, edited by Volkmar Fritz and Aharon Kempinski, 7-34. Wiesbaden: Abhandlungen des Deutschen Palästinavereins.

Knauf, Ernst A. 1984. "Yahwe." Vetus Testamentum 34: 467-72.

Knohl, Israel. 2017. "Jacob-El in the Land of Esau and the Roots of Biblical Religion." Vetus Testamentum 67: 481-84.

Knoppers, Gary N. 2001. "Social Complexity, and Ethnic Diversity in the Genealogy of Judah." Journal of Biblical Literature 120: 15-30.

Koenig, Jean. 1966. "Aux origines des théophanies iahvistes." Revue de l'Histoire des Religions 169: 1-36.

Kristiansen, Kristian, and Thomas Larsson. 2005. The Rise of the Bronze Age Society - Travels, Transmissions and Transformations. Cambridge: Cambridge University Press.

Kutsko, John F. 2000. Between Heaven and Earth. Divine Presence and Absence in the Book of Ezekiel. Winona Lake: Eisenbrauns.

Lanfer, Peter Thacher. 2012. Remembering Eden. The Reception History of Genesis 3:22-24. Oxford: Oxford University Press.

Levy, Thomas E. 2008. "Ethnic Identity in Biblical Edom, Israel and Midian: Some Insights from Mortuary Contexts in the Lowland of Edom." In Exploring the Longue Durée, Essays in Honor of Lawrence A. Stager, edited by David Schloen, 251-61. Winona Lake: Eisenbrauns.

Levy, Thomas E., Russell B. Adams, Mohammad Najjar, A. Hauptmann, James D. Anderson, Baruch Brandl, Mark A. Robinson, and Thomas Higham. 2004. "Reassessing the Chronology of Biblical Edom: New Excavations and 14 C Dates from Khirbat En-Nahas (Jordan)." Antiquity 78: 865-79.

Lipinski, Edward. 2006. On the Skirts of Canaan in the Iron Age: Historical and Topographical Researches. Leuven: Peeters. 
Liu, Siran, Thilo Rehren, Ernst Pernicka, and Arnulf Hausleiter. 2015. "Copper Processing in the Oases of Northwest Arabia: Technology, Alloys and Provenance." Journal of Archaeological Science 53: 492-503.

Martin, Mario A., and Israel Finkelstein. 2013. "Iron IIA Pottery from the Negev Highlands: Petrographic Investigation and Historical Implications." Tel Aviv 40: 6-45.

Master, Daniel M. 2014. "Economy and Exchange in the Iron Age Kingdoms of the Southern Levant." Bulletin of the American Schools of Oriental Research 372: 81-97.

Mather, Tamsin A., and R. Giles Harrison. 2006. "Electrification of Volcanic Plumes." Surveys in Geophysics 27: 387-432.

Mattingly, Gerald L. 2015. "Long-Distance Trade on the Karak Plateau (Central Jordan): The Case of Khirbat Al-Mudaybi and Fajj Al-Usaykir." Review and Expositor 112: 288-300.

Mazar, Amihai. 2003. "Remarks on Biblical Traditions and Archaeological Evidence Concerning Early Israel." In Symbiosis, Symbolism, and the Power of the Past: Canaan, Ancient Israel, and Their Neighbors from the Late Bronze Age Through Roman Palaestina, edited by Seymour Gitin and William G. Dever, 85-98. Winona Lake: Eisenbrauns.

McNutt, Paula M. 1990. The Forging of Israel - Iron Technology, Symbolism, and Tradition in Ancient Society. Sheffield: Almond Press.

Mondriaan, Marleen E. 2010. "The Rise of Yahwism - the Role of Marginalized Groups." Ph.D. dissertation, University of Pretoria.

Nash, Dustin. 2018. "Edom, Judah, and Converse Constructions of Israeliteness in Genesis 36." Vetus Testamentum 68: 111-28.

Negbi, Ora. 1998. "Were There Sea Peoples in the Central Jordan Valley at the Transition from the Bronze Age to the Iron Age? Once Again." Tel Aviv 25: 184-207.

Reid, Andrew, and Rachel MacLean. 1995. "Symbolism and the Social Contexts of Iron Production in Karagwe." World Archaeology 27: 144-61.

Rendsburg, Gary A. 1997. "The Early History of Israel." In Crossing Boundaries and Linking Horizons: Studies in Honor of Michael C. Astour on His 80th Birthday, edited by G. D. Young, M. W. Chavalas, R. E. Averback, and K. L. Danti, 433-53. Potomac: CDL Press.

Richards, Dona. 1981. "The Nyama of the Blacksmith: The Metaphysical Significance of Metallurgy in Africa." Journal of Black Studies 12: 218-38.

Rotea, Mihai, Mihai Wittenberger, Monica Tecar, and Tiberiu Tecar. 2011. "Bronze Age Metallurgy in Transylvania: Craft, Art and Ritual/Magic." Acta Musei Napocensis 45-46: 7-38. Rothenberg, B. 1988. The Egyptian Mining Temple at Timna. London: IAMS. - 1999a. "Archaeo-Metallurgical Researches in the Southern Arabah 1959-1990. Part 2: Egyptian New Kingdom to Early Islam." Palestine Exploration Quarterly 131: 149-75.

- 1999b. "Archaeometallurgical Researches in the Southern Arabah: Late Pottery Neolithic to Early Bronze IV." Palestine Exploration Quarterly 131: 68-89.

Rothenberg, B., and Jonathan Glass. 1983. "The Midianite Pottery." In Midian, Moab and Edom, edited by John F. A. Sawyer, David J. A. Clines, and David J. A. Clines, 65-124. Sheffield: Sheffield Academic Press.

Sauneron, Serge, and Jean Yoyotte. 1959. "La naissance du monde selon l'Egypte ancienne." In La naissance du monde, 17-92. Paris: Seuil.

Sawyer, John F. A. 1986. "Cain and Hephaestus. Possible Relics of Metalworking Traditions in Genesis 4." Abr-Nahrain. An Annual Published by the Department of Middle Eastern Studies, University of Melbourne 24: 155-66. 
Schloen, J. David. 1993. "Caravans, Kenites, and Casus Belli: Enmity and Alliance in the Song of Deborah." Catholic Biblical Quarterly 55: 18-38.

Sergi, Omer. 2013. “Judah's Expansion in Historical Context.” Tel Aviv 40: 226-46.

Smith, Mark S. 2001. The Origins of Biblical Monotheism. Israel Polytheistic Background and the Ugaritic Texts. Oxford: Oxford University Press.

Sparks, Kenton L. 2007. "Religion, Identity and the Origins of Ancient Israel." Religion Compass 1: 587-614.

Stordalen, Terje. 2008. "Heaven on Earth - or Not? Jerusalem as Eden in Biblical Literature." In Beyond Eden - the Biblical Story of Paradise (Genesis 2-3) and Its Reception History, edited by Konrad Schmid and Christoph Riedweg, 28-57. Tübingen: Mohr Siebeck.

Tebes, Juan M. 2003. “A New Analysis of the Iron Age I 'Chiefdom' of Tel Masos (Beersheba Valley)." Aula Orientalis 21: 63-78.

- 2006. "Egypt in the East: The Egyptian Presence in the Negev and the Local Society During the Early Iron Age." Cahiers Caribéens d'Égyptologie 9: 75-93. . 2007. "A Land Whose Stones Are Iron, and Out of Whose Hills You Can Dig Copper. The Exploitation and Circulation of Copper in the Iron Age Negev and Edom." DavarLogos 6: 69-91.

— 2013. "Investigating the Painted Pottery Traditions of First-Millennium BC NorthWestern Arabia and Southern Levant: Chronological Data and Geographical Distribution." Proceedings of the Seminar for Arabian Studies 43: 317-36.

- 2014. "The Symbolic and Social World of the Qurayyah Pottery Iconography." In Unearthing the Wilderness - Studies on the History and Archaeology of the Negev and Edom in the Iron Age, edited by Juan M. Tebes, 163-201. Leuven: Peeters.

- 2017. "The Southern Home of YHWH and Pre-Priestly Patriarchal/Exodus Traditions from a Southern Perspective." Biblica 98: 166-88.

Todesco, Micol, and Ezio Todini. 2004. "Volcanic Eruption Induced Floods. A Rainfall-Runoff Model Applied to the Vesuvian Region (Italy)." Natural Hazards 33: 223-45.

Tsumura, David T. 1989. The Earth and the Water in Genesis 1 and $2-A$ Linguistic Investigation. Sheffield: Sheffield Academic Press.

Tyson, Craig W. 2014. The Ammonites - Elites, Empires and Sociopolitical Change. London: Bloomsbury.

Van der Merwe, Nikolaas J., Donald H. Avery, and Donald H. Avery. 1987. "Science and Magic in African Technology: Traditional Iron Smelting in Malawi." Africa 57: 143-72.

Van der Steen, Eveline J. 1996. "The Central East Jordan Valley in the Late Bronze and Early Iron Ages." Bulletin of the American Schools of Oriental Research 302: 51-74.

Van der Toorn, Karel. 1999. "YHWH." In Dictionary of Deities and Demons in the Bible, edited by Karel Van der Toorn, Bob Becking, Pieter W. van der Horst, and Pieter W. Horst, 910-19. Leiden: Brill.

Van Dyk, Peet J. 2014. "In Search of Eden: A Cosmological Interpretation of Genesis 2-3." Old Testament Essays 27: 651-65.

Veldhuijzen, Xander, and Eveline Van der Steen. 1999. "Iron Production Center Found in the Jordan Valley." Near Eastern Archaeology 62: 195-99.

Watts, John D. W. 1985. Isaiah 1-33. WBC 24. Nashville: Thomas Nelson.

Wenham, Gordon J. 1987. Genesis 1-15. Nashville: Thomas Nelson publishing.

Williamson, Diane. 1990. "The Role and Status of the Bronze Age Smith and the Organization of Metallurgy." Ph.D. dissertation, Durham University. 
Wyatt, Nicolas. 2014. "A Royal Garden: The Ideology of Eden." Scandinavian Journal for the Old Testament 28: 1-35. 